\title{
Submarine lava deltas of the 2018 eruption of Kilauea volcano
}

\author{
S. Adam Soule ${ }^{1}$ (i) $\cdot$ Michael Zoeller ${ }^{2}$ (D) Carolyn Parcheta $^{2}$ (i)
}

Received: 24 June 2020 / Accepted: 26 November 2020 / Published online: 11 March 2021

(C) The Author(s) 2020

\begin{abstract}
Hawaiian and other ocean island lava flows that reach the coastline can deposit significant volumes of lava in submarine deltas. The catastrophic collapse of these deltas represents one of the most significant, but least predictable, volcanic hazards at ocean islands. The volume of lava deposited below sea level in delta-forming eruptions and the mechanisms of delta construction and destruction are rarely documented. Here, we report on bathymetric surveys and ROV observations following the Kỉlauea 2018 eruption that, along with a comparison to the deltas formed at $\mathrm{Pu}^{\prime} u$ ' ${ }^{`}{ }^{`} \mathrm{o}$ over the past decade, provide new insight into delta formation. Bathymetric differencing reveals that the 2018 deltas contain more than half of the total volume of lava erupted. In addition, we find that the 2018 deltas are comprised largely of coarse-grained volcanic breccias and intact lava flows, which contrast with those at $\mathrm{Pu}^{\prime} u^{\prime} \overline{\mathrm{O}}^{\prime} \overline{\mathrm{o}}$ that contain a large fraction of fine-grained hyaloclastite. We attribute this difference to less efficient fragmentation of the 2018 ' $a$ 'a flows leading to fragmentation by collapse rather than hydrovolcanic explosion. We suggest a mechanistic model where the characteristic grain size influences the form and stability of the delta with fine grain size deltas $\left(\mathrm{Pu}^{\prime} \mathrm{u}^{`} \overline{\mathrm{O}}^{`} \overline{\mathrm{o}}\right)$ experiencing larger landslides with greater run-out supported by increased pore pressure and with coarse grain size deltas (Kîlauea 2018) experiencing smaller landslides that quickly stop as the pore pressure rapidly dissipates. This difference, if validated for other lava deltas, would provide a means to assess potential delta stability in future eruptions.
\end{abstract}

Keywords Kilauea $\cdot$ Lava deltas $\cdot$ Submarine landslides $\cdot$ Bathymetry

\section{Introduction}

At most volcanic islands, lava flows that traverse the volcano flanks often reach the coastline. The interaction of hot lava and cold seawater can drive hydrovolcanic explosions both at the coastline and slightly offshore that fragment the lava, which cascades down the submarine slopes (Mattox and Mangan 1997). In some instances, lava can pass quiescently across the waterline and continue as lava flows down shallow submarine slopes. In either case, lava that crosses the coastline is

This paper constitutes part of a topical collection:

The historic events at Kilauea Volcano in 2018: summit collapse, rift zone eruption, and Mw6.9 earthquake

Editorial responsibility: M.R. Patrick; Deputy Executive Editor: J. Tadeucci

S. Adam Soule

adamsoule@uri.edu

1 Graduate School of Oceanography, University of Rhode Island, Narragansett Bay Campus, Narragansett, RI 02882, USA

2 Hawaiian Volcano Observatory, U.S. Geological Survey, Hilo, HI, USA difficult to observe. In this study, we consider lava deltas to be the submarine fan of clastic and intact material that is deposited (and in cases remobilized) below the waterline where lava flows enter the sea. At the coastline, lava deltas are capped by lava benches, areas of flat-lying, subaerial lava flows that are built upon delta material. Submarine lava deltas and subaerial lava benches pose a unique hazard on ocean island volcanoes. Landslides of delta material, that in some cases can extend to and include collapse of lava benches, can produce locally catastrophic results, including increased hydrovolcanic explosions (onshore and offshore), ejection of blocks, and generation of local tsunami waves (Mattox and Mangan 1997; Chiocci et al. 2008; Poland and Orr 2014). Unfortunately, there are limited means to predict the timing and size of bench/delta collapses. This is due, in part, to a limited understanding of the patterns of submarine lava transport and deposition, properties of delta material, mechanisms and modes of failure, and how these properties vary with lava flow type, flux, and composition. This study examines lava deltas produced in the 2018 eruption of Kîlauea Volcano, compares them to those that formed at $\mathrm{Pu}^{\prime} u$ ' $\bar{O}^{‘} \bar{o}$ over decadal time scales, and provides new insight about delta formation and evolution. 
Lava flows from the 2018 eruption of Kîlauea Volcano reached the coastline and constructed over $3.5 \mathrm{~km}^{2}$ of new land. The 2018 ocean entries, with lava delivered at high flux and as ' $a$ 'ā rather than pāhoehoe flows, present a useful contrast with ocean entries of the previous 35 years during the $\mathrm{Pu}^{\prime} u{ }^{\prime} \bar{O}^{`} \bar{o}$ eruption. New bathymetric mapping conducted at the cessation of the eruption, seafloor observations from $\mathrm{ROV}$, and observations from land provide a unique data set to examine the development of lava deltas during a high effusion rate Hawaiian eruption (Fig. 1).

\section{Background}

As lava flows reach the coastline a variety of mechanisms lead to fragmentation. The heating of seawater to steam can drive hydrovolcanic explosions that fragment the lava (e.g., Moore and Ault 1965; Mattox and Mangan 1997; Poland and Orr 2014). The intensity of these explosions depends on the mechanisms by which water and lava mix (Zimanowski et al. 1997) and can range from no explosions as observed at the Mauna Loa 1950 ocean entries (Finch and Macdonald 1955; Moore et al. 1973) to highly energetic explosions that produce littoral cones and abundant fine-grained volcaniclastics best described as very fine sand or ash (Moore and Ault 1965; Tribble 1991; Dobran and Papale 1993; Mattox and Mangan 1997). Even without explosions, lava may still fragment when entering the water by quench granulation or wave impacts that produce sand- to pebble-sized grains termed hyaloclastite (Watton et al., 2013), or by gravity-driven breakup of intact lava (Skilling 2002) that produce cobble- to boulder-sized clasts termed volcaniclastic breccia (Fisher 1960; Yamagishi 1987). In some instances, lava flows may cross the coastline without fragmentation, producing intact lava flows that extend down the submarine volcano flank (Mitchell et al. 2008).

There is no consensus on the relative proportions of intact and fragmental lava that are produced in the formation of lava deltas. Examples of fast and slow-moving ' $a$ 'a flows and pāhoehoe flows that enter the water either quiescently or with significant fragmentation can be found. In most cases, these observations are restricted to the shoreline. However, we are aware of direct observations of active delta formation at shallow water depths via SCUBA during two Kîlauea eruptions: for the Mauna Ulu eruption, a single-day ' $a$ 'a flow in 1969 then nearly 4 months of pāhoehoe flows in 1971 (Moore et al. 1973), and for the $\mathrm{Pu}^{\prime} \mathrm{u}{ }^{\prime} \overline{\mathrm{O}}^{`} \mathrm{o}$ eruption, nearly 5 months of pāhoehoe flows in 1989 (Tribble 1991). In both cases, divers documented downslope transport of fragmental lava ranging from sand-sized to cobble-sized grains that were presumably generated at the coastline. In addition, intact lava flows including pillows, tubes, and channels were observed to form at water depths up to the dive limit of $70 \mathrm{~m}$. The development of submarine lava channels observed at the $\mathrm{Pu}^{\prime} u{ }^{\prime} \overline{\mathrm{O}}^{‘} \bar{o}$ delta was interpreted to reflect the concentrated delivery of large volumes of lava at the coastline (Tribble 1991), implying that flux may be an important control on the ability for intact flows to form underwater. The 1971 Mauna Ulu delta was nearly entirely composed of fragmental lava as intact lava flows became unstable and fragmented during slumping and as thin streams of lava flowing over the sea cliff quenched and
Fig. 1 Lava flows of the 2018 Kîlauea eruption (pink) erupted from the volcano's East Rift Zone and covered $35.5 \mathrm{~km}^{2}$. Lava flows reached the coastline at several locations, producing ocean entries that spanned more than $6 \mathrm{~km}$. Lava was deposited in the ocean and produced deltas with thickness (derived from pre- and post-eruption bathymetric surveys) up to $250 \mathrm{~m}$ that extend more than $1 \mathrm{~km}$ from the new coastline and to water depths of $750 \mathrm{~m}$. The location of the map relative to the Island of Hawaii is shown in the upper left inset

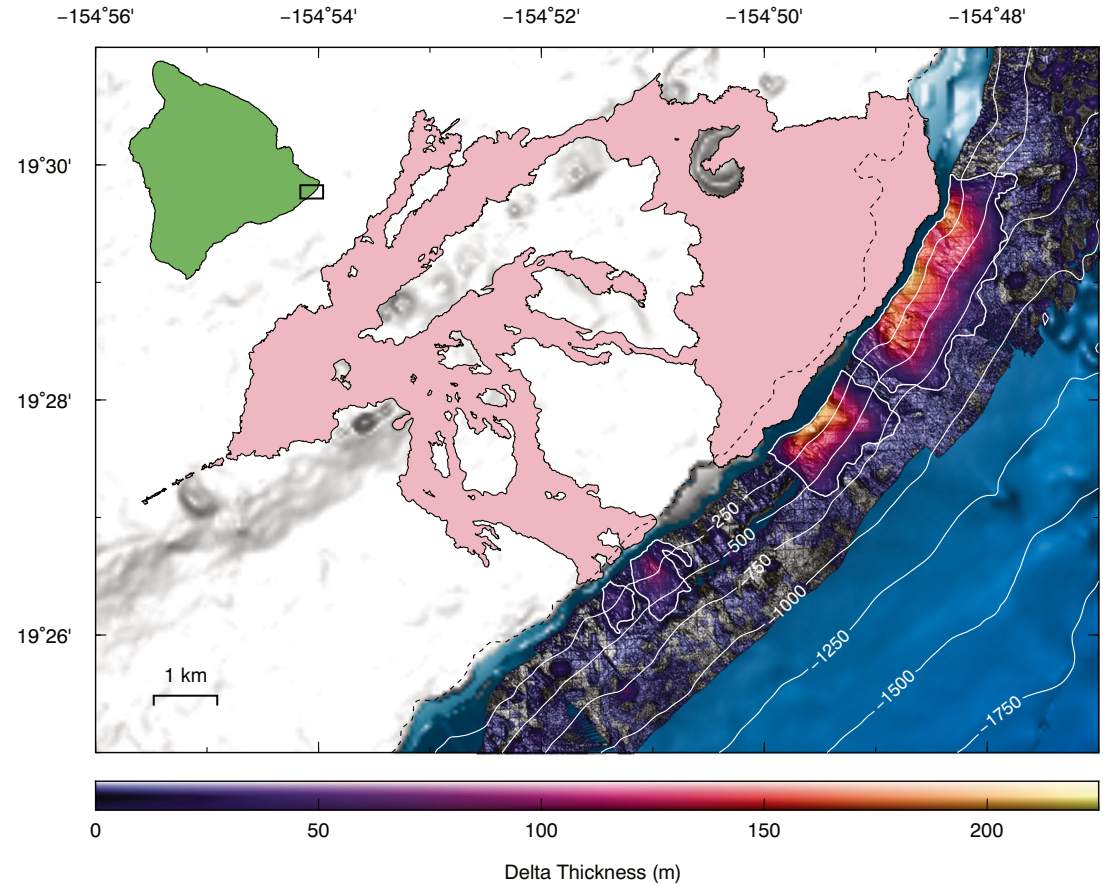


fragmented (Moore et al. 1973). Although the 1971 Mauna Ulu submarine delta is described as being dominated by hyaloclastite, small areas of lava talus (i.e., volcaniclastic breccia) with slopes of $35-40^{\circ}$ are also mentioned. The $\mathrm{Pu}^{6} \mathrm{u}$ 'Ō'o delta was described as being covered by $20 \%$ intact lava, the rest being sediment of indeterminate size (Tribble 1991). These observations contrast with SCUBA observations of Etnean lava flows that entered in the ocean that report little to no fragmental material other than broken pillow fragments (Moore et al. 1971), but are similar to observations during and after the development of lava deltas from the Stromboli 2007 eruption (Bosman et al. 2014) that also found a mix of fragmental and intact lava flows.

SCUBA observations that provide a highly localized view of active processes are consistent with observations from uplifted ancient successions (e.g., Yamagishi 1987; Skilling 2002; Watton et al. 2013), which offer a more holistic view of delta structures and lithologies. In Icelandic deposits, the range of lithologies identified provides context for observations from the Kîlauea 2018 deposits. The lithologies are broadly distinguished by clast morphometry with varying proportions of fine-grained and coarse-grained material as well as by whether they indicate primary (e.g., pillow lava) or synsedimentary (e.g., pillow breccia) deposition (Watton et al. 2013). These deposits can also provide evidence for the evolution of the depositional environment through time and across the air-water interface.

Most ancient lava deltas described in the literature were fed by pāhoehoe lava flows, which are inferred to more efficiently fragment as they cross the air/water interface due to thinner flows, lower flow rates, and higher porosities (Jones and Nelson 1970; Moore et al. 1973; Skilling et al., 2002). Smellie et al. (2013) describe the distinctive characteristics of an 'a'ā-fed lava delta from East Antarctica of late Miocene-Pliocene age. They note that ' $a$ 'a $\bar{a}$ deltas contain a greater proportion of intact flows and coarser grain sizes than pāhoehoe-fed deltas. They also note shallower delta slopes for 'a'ā vs. pāhoehoe-fed deltas.

Failure of volcanic slopes represents a significant hazard common to most coastal volcanoes. The size of landslides can span a range of magnitudes from small landslides to enormous sector collapses (Moore et al. 1994). Lava delta collapse represents an important example of volcanic slope failure that, while small in scale, occur in areas that are heavily trafficked by visitors and, at present, are difficult to forecast as they largely occur underwater (Poland and Orr 2014). Failures of submarine lava deltas on Kîlauea Volcano have been recorded by visual observations at subaerial ocean entries (Mattox and Mangan 1997; Poland and Orr 2014) and hydroacoustically (Caplan-Auerbach et al. 2001). In addition, hydroacoustic observations and repeat bathymetric surveys have documented landslides of a similar scale at many submarine volcanoes (e.g., Chadwick et al. 2011; Watts et al. 2012; Caplan-
Auerbach et al. 2014), especially those dominated by clastic deposits.

In the case of $\mathrm{Pu}^{\natural} \mathrm{u}$ ' $\overline{\mathrm{O}}^{`} \overline{\mathrm{o}}$ deltas, nearly all documented collapses occur during periods of volcanic accretion [Neal and Anderson 2020], supporting a model wherein collapse is initiated via oversteepening of growing delta slopes. Rare exceptions include the East Laeapuki delta that experienced a partial collapse 2 months and full collapse 5 months after the entry stopped. In addition, the May 4, 2018, collapse of the Kamokuna delta occurred after the $\mathrm{Pu}^{\prime} \mathrm{u}$ ' $\overline{\mathrm{O}}^{`} \overline{\mathrm{o}}$ eruption had ceased and is believed to have been initiated from earthquake shaking. Along with oversteepening during accretion and seismic shaking, ground deformation and wave energy have also been proposed as drivers of submarine slope failure (Masson et al. 2006). As we will discuss, the 2018 deltas did not experience any bench collapses during their emplacement and showed only minor hydroacoustic evidence of downslope transport (Caplan-Auerbach et al. 2019).

\section{Description of the 2018 eruption}

The events of the 2018 Kinlauea eruption have been described in detail by Neal et al. (2019); the most relevant details for this study are the timing and duration of lava flows entering the ocean. The first two ocean entries, fed by fissures 20 and 22, began simultaneously on the night of May 19 near the MacKenzie State Recreation Area. The eastern entry from fissure 20 ended within a day as that vent's effusion rate dropped. However, fissure 22's lava was able to commandeer the fissure 20 channel, in addition to its own, and sustain both ocean entries for another 10 days. The third ocean entry, also in the MacKenzie delta complex, was produced by a joint flow from fissures 6 and 13. It reached the ocean on May 22 and continued activity until May 28. All three entries, which clustered along a $1.5-\mathrm{km}$ stretch of coastline, consisted of an 'a'à lava channel that entered directly into the ocean; no explosions were observed at these entries.

The fissure 8 lava flow, the main flow of the eruption, reached the ocean at Kapoho Bay in the late evening of June 3. The entire shallow bay was filled in with lava within $48 \mathrm{~h}$, forming a broad point that continued to enlarge eastwards through June. Again, the ocean entry was dominated by a single ' $a$ 'a channel feeding directly into the ocean and no significant explosions were observed. The lava channel slowly migrated south from June 6 to June 29 and the style of ocean entry changed from a single channel to dozens of weak entries along the entire 4-km-long flow front. On June 29, a breakout near Kapoho Crater shifted lava back to the north side of the original ocean entry location in Kapoho Bay. A similarly unexpected breakout shifted lava back to the south in early July, with lava once again flowing in an open channel to the sea along the south margin of the delta - as it existed then. 
Starting around the end of June, several hydrovolcanic explosions were observed. Most eyewitness reports came from lava tour boats, although there was also a more robust laze plume, indicating that more lava was interacting with the sea water than in the first 2 weeks of June. A major reconfiguration of the lava channel west of Kapoho Crater on July 9 caused lava to be diverted away from the original 4-km-long flow front, creating a new ocean entry to the south near Ahalanui. This became the focus of coastal activity for the rest of July, with a southwestward migration throughout the month and further explosions observed, including one that injured several tour boat passengers on July 16. As with the Kapoho entry, this lobe of the fissure 8 delta sustained dozens of weaker, oozing lava entries along its margin, which grew to be $2.4 \mathrm{~km}$ wide. Fissure 8 effusion ceased on August 4 and the lava channel drained within $24 \mathrm{~h}$. Nevertheless, dozens of weakly effusive entries persisted along the flow front for the following 10 days.

\section{Methods}

Multibeam sonar data was collected along the south coast of Kilauea Volcano on August 19, 20, 27, and 28 with a Kongsberg EM302 multibeam echosounder on the research vessel E/V Nautilus. Surveys were run parallel to the coastline from water depths of $4000 \mathrm{~m}$ to $\sim 200 \mathrm{~m}$. Trackline spacing varied from $<100 \mathrm{~m}$ to $\sim 1 \mathrm{~km}$ to accommodate the variable water depths. Multibeam sonar data were processed using QPS Qimera ${ }^{\mathrm{TM}}$ where corrections for variations in sound speed and tides were applied. In addition, water column backscatter data were processed with QPS Qimera ${ }^{\mathrm{TM}}$, and the position of mid-water anomalies was highlighted (Soule et al. 2019). Bathymetric data were gridded at 50-m resolution for the entire data set and at $5-\mathrm{m}$ resolution for the survey lines closest to the coast (i.e., in the shallowest water) to produce model seafloor surfaces. Bathymetric surfaces collected in 2006 by the R/V Kilo Moana EM1002 (Smith 2016) were subtracted from the new high-resolution surfaces to isolate changes in seafloor depth resulting from volcanic deposition (e.g., Chadwick et al. 1991, 2008; Wright et al. 2008; Caress et al. 2012). These thickness maps were created for the lava deltas produced during the 2018 eruption as well as those at $\mathrm{Pu}^{\prime} \mathrm{u}$ ' $\overline{\mathrm{O}}{ }^{\prime} \bar{o}$, which experienced deposition as well as erosion from several documented bench collapses during this time period (Poland and Orr 2014; Hawaiian Volcano Observatory, 2020).

Potential rotations and translations between pre- and posteruption surfaces, reflecting differences in quality of ship positioning data and processing methods between the surveys, were examined by minimizing misfit between surfaces via iterative closest point matching in CloudCompare (ver 2.10.2). The area of deposition for the 2018 lava flows did not require any transformation, and the area around the $\mathrm{Pu}$ ' $\mathrm{u}$ ' $\bar{O}^{`} \bar{o}$ lava deltas required a small translation and rotation (Supplementary Figure 1). Gridded bathymetric data, prior to any translation or rotation, is available for download from the Marine Geoscience Data System archive (www.mgds. org).

Seafloor observations and samples were collected on a single, 12-h dive with ROV Hercules on September 10. The dive initiated at a depth of $175 \mathrm{~m}$ and traversed eastward along the lava delta, parallel to the coastline, for $2 \mathrm{~km}$. The ROV then moved to deeper water (out of visual contact with the seafloor) before traversing along the delta slope to the west at 650 $700 \mathrm{~m}$ water depth for $700 \mathrm{~m}$ (Fig. 2). Five rock samples were collected during the dive from the range of lithologies observed at the base of the delta. Fluid samples were collected and water temperatures were measured by thermocouple at sites of fluid egress around lava flows (German et al. 2018).

Rock samples were analyzed for bulk major and trace element composition via XRF at University of Massachusetts Amherst following the methods described in Rhodes (1996) and Rhodes and Vollinger (2004). Samples were crushed and cleaned in deionized water and picked for alteration-free chips. Chips were powdered with an agate pulverizer and fused into glass beads. Standards BHVO-1 and BHVO-2 were run before and after the samples. Major and trace element concentrations are reported in Supplementary Tables 1, 2. In addition, sample NA099-111 of intact lava from the delta toe was mounted in epoxy and polished to $1 \mu \mathrm{m}$ and imaged with a benchtop scanning electron microscope (Hitachi TM3000) for textural analysis.

\section{Results}

\section{Kïlauea eruption deltas}

A series of four discrete lava deltas, or delta complexes, were emplaced by 2018 lavas along an approximately $10-\mathrm{km}$ stretch of coastline. We identify lava deltas as distinct and coherent regions of lava accumulation (i.e., positive seafloor change). For convenience, we refer to the deltas as the Kapoho delta, the Ahalanui delta, and the MacKenzie 1 and 2 deltas. The Kapoho and Ahalanui deltas are broad (2-3 km wide) and extend $1.2 \mathrm{~km}$ from the new coastline (Fig. 2a). The two MacKenzie deltas are significantly narrower (Fig. 2b) and extend $0.7 \mathrm{~km}$ and $1 \mathrm{~km}$ from the coastline.

The Kapoho delta, seaward of the former Kapoho Bay, appears to be a complex of at least three merged lobes, separated by narrow gullies. The central lobe is unique among this group, with a largely featureless rounded surface. The southern lobe contains narrow, high-relief ridges oriented radially to the delta head. The northernmost lobe also displays highrelief ridges, but these emerge midway down the delta slope. 


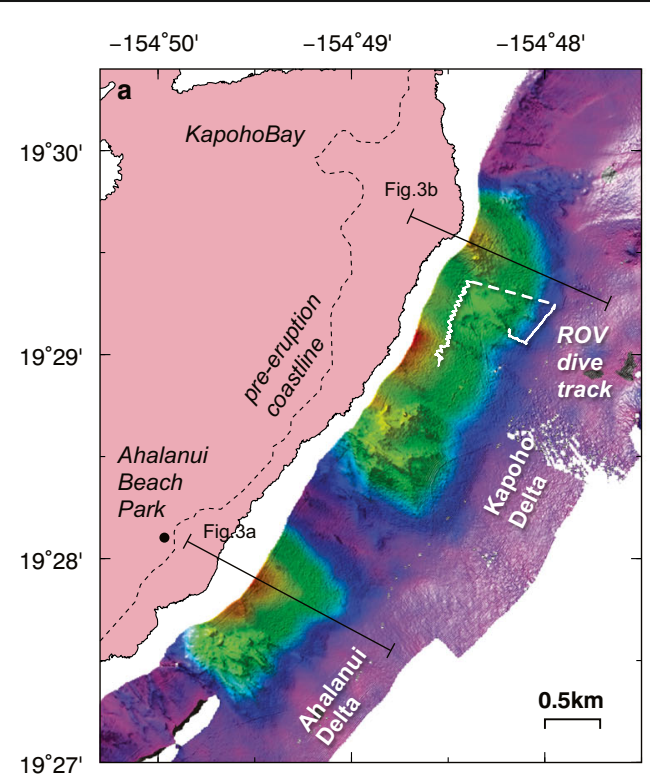

Fig. 2 a Larger deltas near the former Kapoho Bay and Ahalanui Beach Park contain areas of rough topography adjacent to regions of smooth slopes. The rough topography is characterized by elongate ridges, some of which originate mid-slope. The white line indicates the track of the

Notably, reflections in the water column, as are observed in particle plumes around hydrothermal vents, were detected during multibeam sonar surveys at the landward edge of this mid-slope ridge network (Soule et al. 2019). Similar ridge features are observed in the 2011 Stromboli lava deltas and are interpreted as lava flows (Bosman et al. 2014). The two smaller MacKenzie deltas appear to be comprised entirely of ridges. In addition to linear ridges, there are hummocky areas comprised of small (20-100 m wide), overlapping mounds, reminiscent of pillow ridge morphology of some mid-ocean ridge lava flows (Soule 2015).
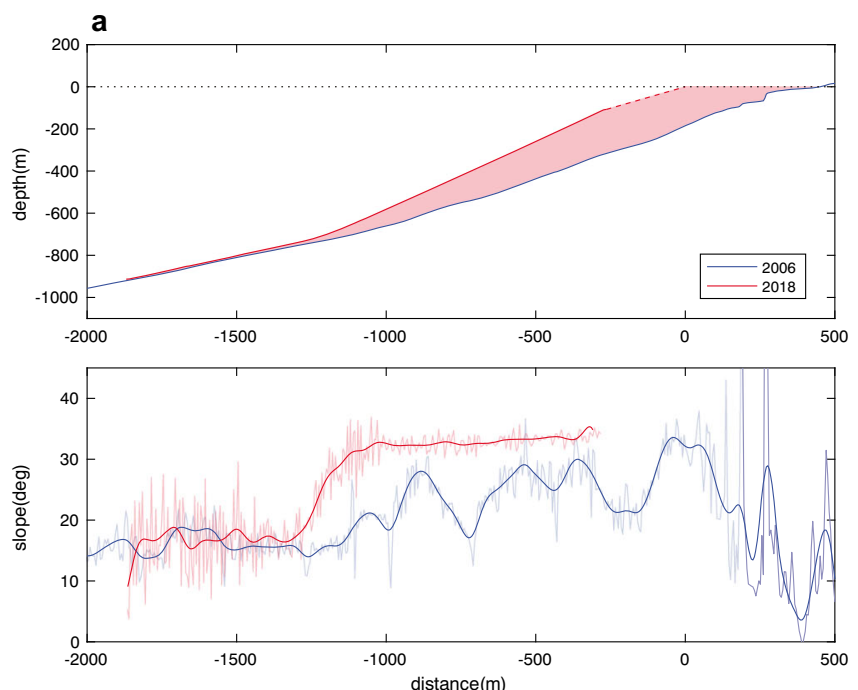

Fig. 3 Slopes along profiles for Ahalanui delta (a) and the Kapoho delta (b). Profile locations are shown in Fig. 2. The pre- and post-eruption surfaces (top) are shown in blue and red respectively and areas of

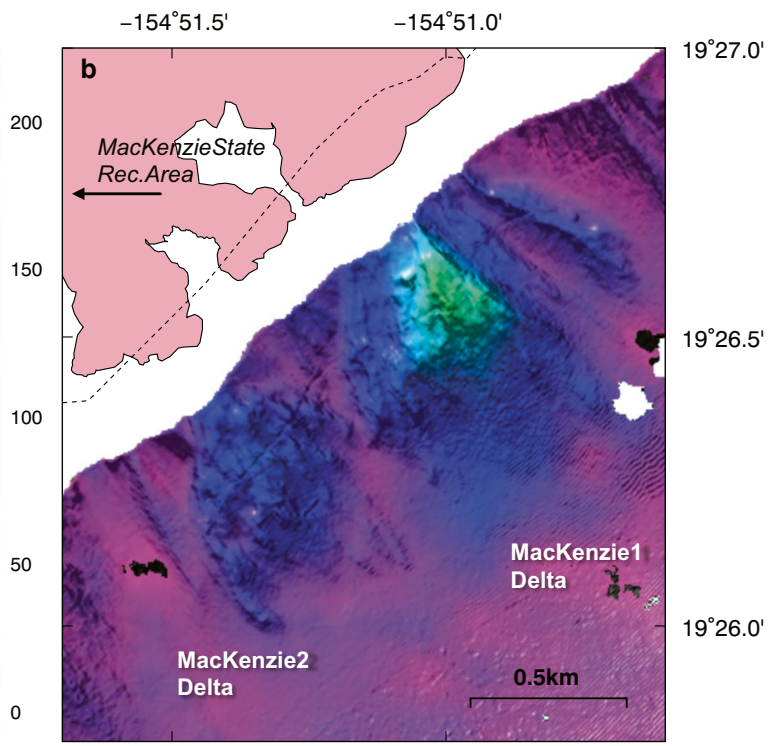

ROV dive. b Smaller deltas from the MacKenzie State Recreation Area have rough, hummocky topography with some elongate ridges. The front of the larger delta has a smooth seaward slope

Deltas are thickest near the coastline and taper seaward (Fig. 2). The maximum delta thickness is found in the Kapoho Bay area at over $200 \mathrm{~m}$. The seaward extent of the deltas may extend slightly farther than mapped because thicknesses drop below what is detectable by this method $(\sim 5 \mathrm{~m})$. The slopes of the larger deltas, as measured on their centerlines range from 20 to $35^{\circ}$, and generally increase by $10-15^{\circ}$ over pre-eruption slopes (Fig. 3). The greatest increases in slope correlate with the greatest thickness and extend, in some cases, more than a kilometer from the current coastline. The
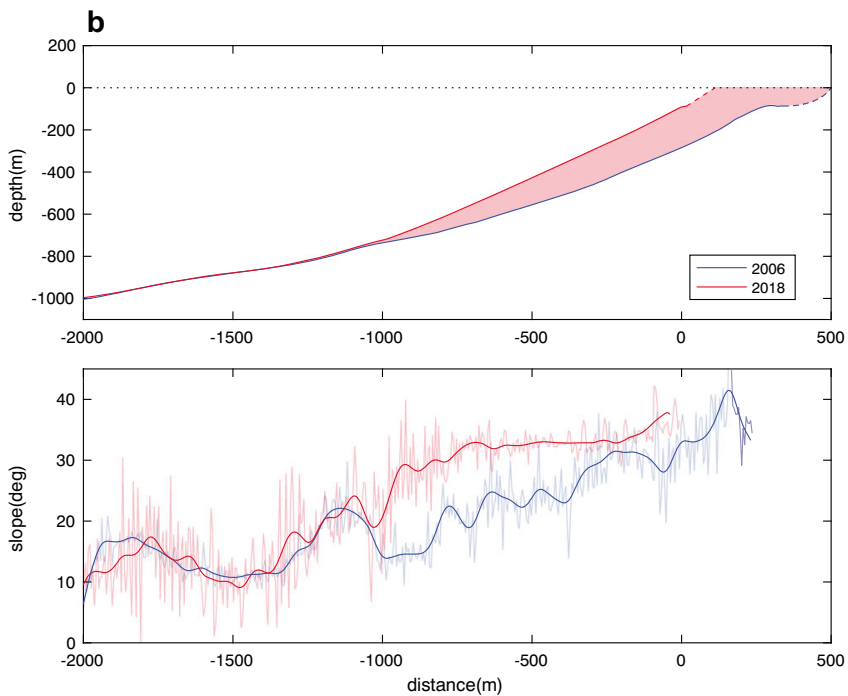

deposition are shown by light red fill. The pre- and post-eruption slopes are shown in blue and red (bottom) with a low-pass filtered signal in dark colors and the raw signal in light colors 
MacKenzie deltas show more modest slopes of $15-20^{\circ}$ and are consistent with pre-eruption slopes.

The bulk volume deposited in the ocean from the 2018 Kîlauea eruption, defined as any new material deposited below sea level, is $759 \times 10^{6} \mathrm{~m}^{3}$ (Table 1), which is roughly $60 \%$ of the estimated total eruption volume (Neal et al. 2019). Bulk volume of the submarine deposits is calculated as the integrated depth difference between 2018 and 2006 bathymetric maps within manually digitized regions of coherent depth reduction (e.g., Chadwick and Embley 1995; Caress et al. 2012; Carey et al. 2018). This volume is added to the calculated volume between the prior and current coastlines excluding volume deposited above sea level. This is calculated from posteruption lidar and UAS topographic maps (Dietterich et al. 2020). Also included is the volume accounted for by a swath that is $\sim 200 \mathrm{~m}$ wide between the new coastline and the landward edge of the bathymetric survey. For this area, thickness is interpolated between the bathymetry-derived thickness and lidar/UAS-derived thickness via a natural neighbor algorithm in order to estimate volume (Supplementary Fig. 2). Error estimates on volume include are determined from uncertainties of depth differences calculated in areas of no lava accumulation, which show mean differences near zero and a $2 \sigma$ range of depth differences of $\pm 10 \mathrm{~m}$ (Supplementary Fig. 3) (Friant et al. 2010).

\section{Delta material}

The lithologies that make up the 2018 deltas are identified from seafloor imagery collected along ROV transects. The transects (Fig. 2) crossed $\sim 3 \mathrm{~km}$ of the Kapoho delta at $250 \mathrm{~m}$ water depth (mid-slope) and $\sim 1 \mathrm{~km}$ of the same delta at 750 -m water depth (delta base). Coarse-grained clastic material dominated the lava deltas with grain size and sorting varying by location. Very fine-grained ash was also visible in nearly all locations visited as a layer of tan sediment mantling the volcanic breccia and lava flows. Lava flows were observed at the delta base, in areas of notable ridges in the bathymetry. We describe the delta lithologies by grain size below:

\section{Fine grained}

Much of the observed delta was covered by tan-colored, very fine-grained sediment with an appearance similar to hemipelagic mud. The thickness of the sediment generally increased downslope with accumulations of up to $10 \mathrm{~cm}$ found towards the base of the delta (Fig. 4). Portions of the upper delta were sediment free (Fig. 4b,c), possibly due to late-stage mass movement rather than a lack of sedimentation, as the sediment-free areas were typically well-sorted and adjacent areas had significant sediment. No evidence of sandsized grains, as described for other Hawaiian deltas (Moore et al. 1973; Tribble, 1991; Sansone and Smith, 2006) was observed, although it may be present in interstices of the breccia. Sediment samples were not collected.

\section{Coarse grained}

Volcanic breccias dominate the portions of the delta observed, with grain sizes from 5 to $50 \mathrm{~cm}$ as determined from calibrated lasers on the ROV. Rare large blocks up to $1 \mathrm{~m}$ in diameter were observed (Fig. 4a-c). The volcanic breccias are comprised of angular blocks of lava that display textural features of ' $a$ 'a a flow interiors including high-crystallinity and complex vesicles (Fig. 4d). Where inspected and sampled, most blocks are dense $(<5 \mathrm{vol} \%$ vesicles) and contain minor amounts of glass. Volcanic breccias are moderately sorted within downslope bands indicative of small-scale mass wasting events. Contacts between these landslide deposits show variations in grain size and sediment cover. Small landslide bands are on the order of $10 \mathrm{~m}$ in width, but larger deposits are unlikely to be recognized by the mode of observation (i.e., near-bottom, along-slope transects).

\section{Lava flows}

One distinct intact lava flow was observed in the distal portion of the delta at a depth of $\sim 700 \mathrm{~m}$. The lava flow emerged from a cover of volcanic breccia and was at least $3 \mathrm{~m}$ thick. The
Table 12018 Kỉlauea eruption submarine delta properties

\begin{tabular}{lrcc}
\hline Delta & Volume $\left(\times 10^{6} \mathrm{~m}^{3}\right)$ & Area $\left(\times 10^{5} \mathrm{~m}^{2}\right)$ & Mean thickness $(\mathrm{m})$ \\
\hline Kapoho & 335.44 & 41.20 & 81.41 \\
Kapoho (lidar) & 89.28 & 22.85 & 41.72 \\
Kapoho (inferred) & 67.29 & 4.89 & 128.3 \\
Ahalanui & 144.89 & 18.44 & 78.55 \\
Alahanui (lidar) & 47.70 & 8.53 & 55.90 \\
Alahanui (inferred) & 42.00 & 3.20 & 129.80 \\
MacKenzie 1 & 25.75 & 7.05 & 36.52 \\
Mackenzie 2 & 6.95 & 2.68 & 25.97 \\
Total & $759 \pm 110$ & 108.84 &
\end{tabular}


Fig. 4 Frame-grabbed images from ROV video show the range of lithologies present on the lava deltas. An approximate 1-m scale (white bar) is determined from laser points separated by $10 \mathrm{~cm}$ on the ROV. a Well-sorted

brecciated lava fragments 10 $30 \mathrm{~cm}$ in diameter. b A poorly sorted chute of breccia fragments $10 \mathrm{~cm}$ to $1 \mathrm{~m}$ in diameter sits within a heavily sedimented channel. c A contact between a well-sorted, fine-grained $(<10 \mathrm{~cm})$ region and a poorly sorted coarser grained region. d Close up of a breccia fragment showing convoluted (i.e., 'a'ālike) vesicles. Approximate field of view is $30 \mathrm{~cm}$. e Lava flow with dense core and rough upper and lower surfaces. f Area of fluid flow supporting yellow-orange, Fe-oxidizing bacteria along lava flow
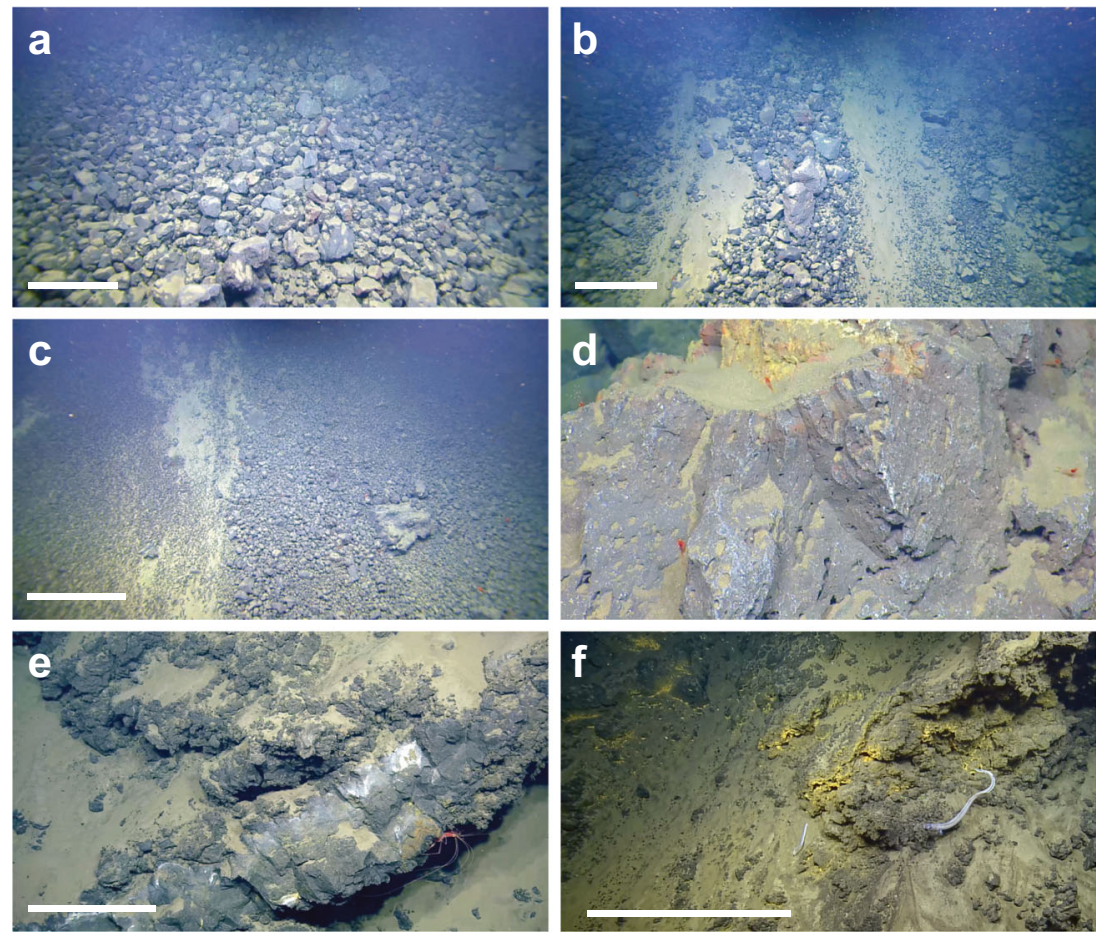

flow resembled an 'a'a flow with a dense interior and rough upper surface, but lacked a carapace of autobrecciated lava (Fig. 4e).

\section{Hydrothermal and biological}

Around the lava flow and in some areas of volcanic breccia there was evidence of fluid reacting with hot rock, recognized by the presence of bacterial mats (Fig. 4f). Iron-oxidizing bacteria, similar in appearance to those observed on the delta, colonize the hydrothermally active Lō'ihi seamount roughly $75 \mathrm{~km}$ to the southwest. Samples of the circulating fluids collected within a crack around the lava flow showed temperatures slightly above $\left(<1^{\circ} \mathrm{C}\right)$ ambient seawater indicating that the seawater was interacting with hot rock. The precise time of deposition of this lava flow is not known, but is likely on the order of 1 month prior to the ROV dive.

\section{Geochemistry and petrology}

The chemical composition of 2018 Kîlauea lava evolved through a series of phases over the course of the eruption due to mixing of freshly injected mafic magma with evolved magmas stored in the rift zones from prior eruptions (Gansecki et al. 2019). ROV-collected lava samples from the Kapoho delta that was fed by fissure 8 have major and trace element compositions (Supplementary Tables 1,2 ) that are nearly identical to the "Phase 3" whole-rock compositions of Gansecki et al. (2019), the least evolved lavas of the eruption (Fig. 5). This compositional similarity confirms that the deltas imaged by bathymetric mapping and ROV, including both the clastic components and intact lava flows were sourced from the Kîlauea 2018 eruption.

Texturally, the submarine lava flow samples contain domains of higher and lower crystallinity lava separated by a thin layer of Fe-oxides (Fig. 6). The growth of oxides into the lower crystallinity lava and the preferred orientation of plagioclase laths around the crystalline domains suggest that the crystal rich regions may be exotic to the magma. This texture is similar to those observed in samples from lava fountains and other low-intensity explosive eruptions that experience clast recycling (Deardorff and Cashman 2017). Ejected fragments that have cooled and crystallized and whose outer surfaces have oxidized in ambient air are reincorporated into the magma. The oxidized and cooled clast surfaces cause the precipitation of $\mathrm{Fe}$-oxides as the clasts begin to equilibrate with the host magma. Low fountaining $(20-80 \mathrm{~m})$ persisted at fissure 8 over the duration of its activity (Patrick et al. 2019) and could be the origin of these textures. If so, it is somewhat remarkable that they remain intact, largely undeformed, and do not thermally re-equilibrate over their $13-\mathrm{km}$ transit to the coastline followed by a $1.2-\mathrm{km}$ transit down the submarine flank of Kīlauea. Alternatively, these clasts may reflect autobrecciated ' $a$ ' $a \overline{~ c l a s t s ~ r e i n c o r p o r a t e d ~ i n t o ~ t h e ~ l a v a ~ f l o w ~}$ during its transit to the coast or at the coastline. The incorporation of lava crusts into a flow's molten interior has been observed in active Hawaiian lava channels (Cashman et al. 1999) and at lava falls (Kauahikaua et al. 1998). Regardless of their origin, it is unlikely that this type of recycling or clast incorporation would be easily visible in lava flows deposited 
Fig. 5 Compositional variations of 2018 Kỉlauea eruption lava are indicated by different colored dots. Eruption phases reflect mixing an increasing proportion of a mafic end member with evolved compositions from magmas stored in the rift zone (Gansecki et al. 2019). Phase 3 lava compositions (dark blue) represent the mafic end member and are compositionally identical to samples from the submarine Kapoho delta that are indicated by red lines. Phase 3 erupted largely from fissure 8 , and fed the Kapoho delta. Samples from this study are indicated by the cross points of red lines

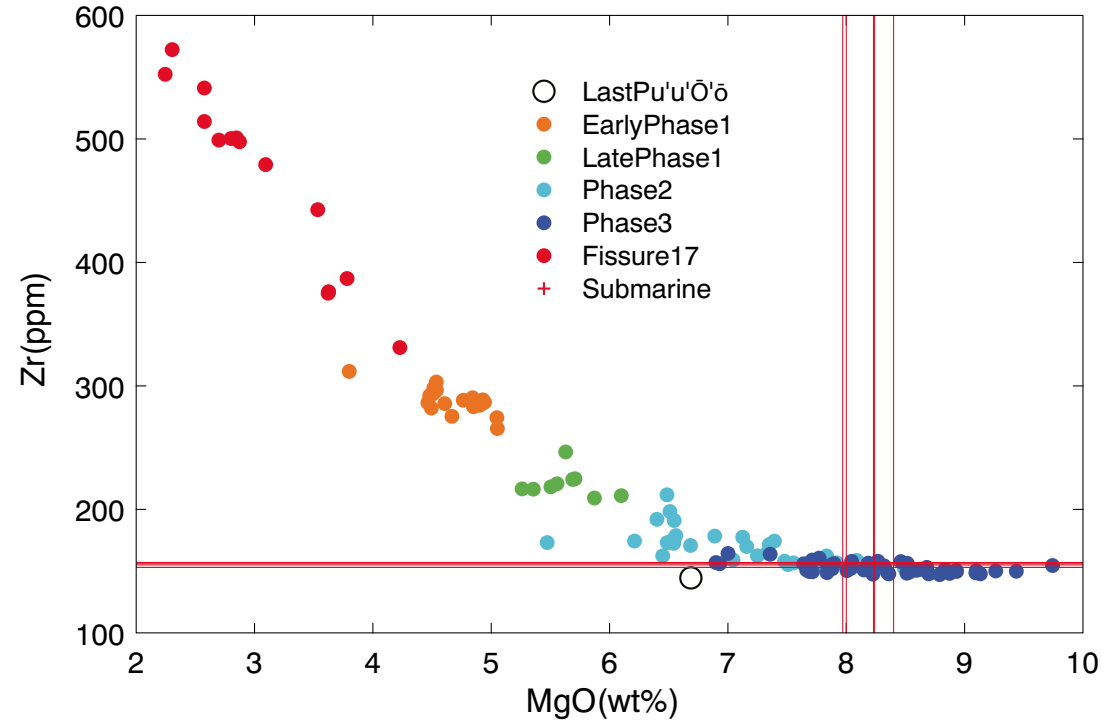

on land due to slower cooling rates leading to more complete groundmass crystallization.

\section{Pu`u ‘ō'ō deltas}

The $\mathrm{Pu}^{6} \mathrm{u}$ ' $\mathrm{O}^{‘}$ ō eruption of Kīlauea delivered pāhoehoe lava flows to the volcano's southeast coastal plain and into the ocean intermittently over a period of 35 years (1983-2018). The lava deltas produced by this eruption, perhaps unsurprisingly given the difference in flow type, are distinctly different than those from the 2018 eruption. We describe the delta growth after 2006, the time of the previous high-resolution bathymetric survey (Smith, 2016). The primary delta, located at the east end of the $\mathrm{Pu}^{\prime} \mathrm{u}$ ' $\mathrm{O}^{`}$ o flow field, is much longer than the 2018 examples. It extends more than $5 \mathrm{~km}$ from the coastline, but is significantly thinner $(\max =85 \mathrm{~m})($ Fig. 7). In addition, there are a number of smaller deltas (i.e., areas of accretion) that form in downslope of areas of erosion. These secondary deltas (i.e., deltas produced by remobilization of material) occur at areas of known significant collapse including those in 2007 (East Laeapuki, Poland and Orr, 2014) and 2016 (Kamokuna, Hawaiian Volcano Observatory 2020). The

Fig. 6 SEM images show basaltic glass (light gray), plagioclase feldspar (dark gray), Fe-oxides (bright white), and olivine and pyroxene crystals (medium gray). Regions of high- and lowcrystallinity lava are separated by bands of concentrated Fe-oxides $(\mathbf{a}, \mathbf{c})$, which are also present as a dispersed phase $(\mathbf{b}, \mathbf{c})$. The boundaries between regions are convoluted and in most cases, the more crystalline material encloses the less crystalline material (a, c). We interpret the more crystalline material as recycled clasts. Outside of the recycled clasts, plagioclase crystals show a preferred alignment, parallel to the boundary of the more crystalline domain (b)
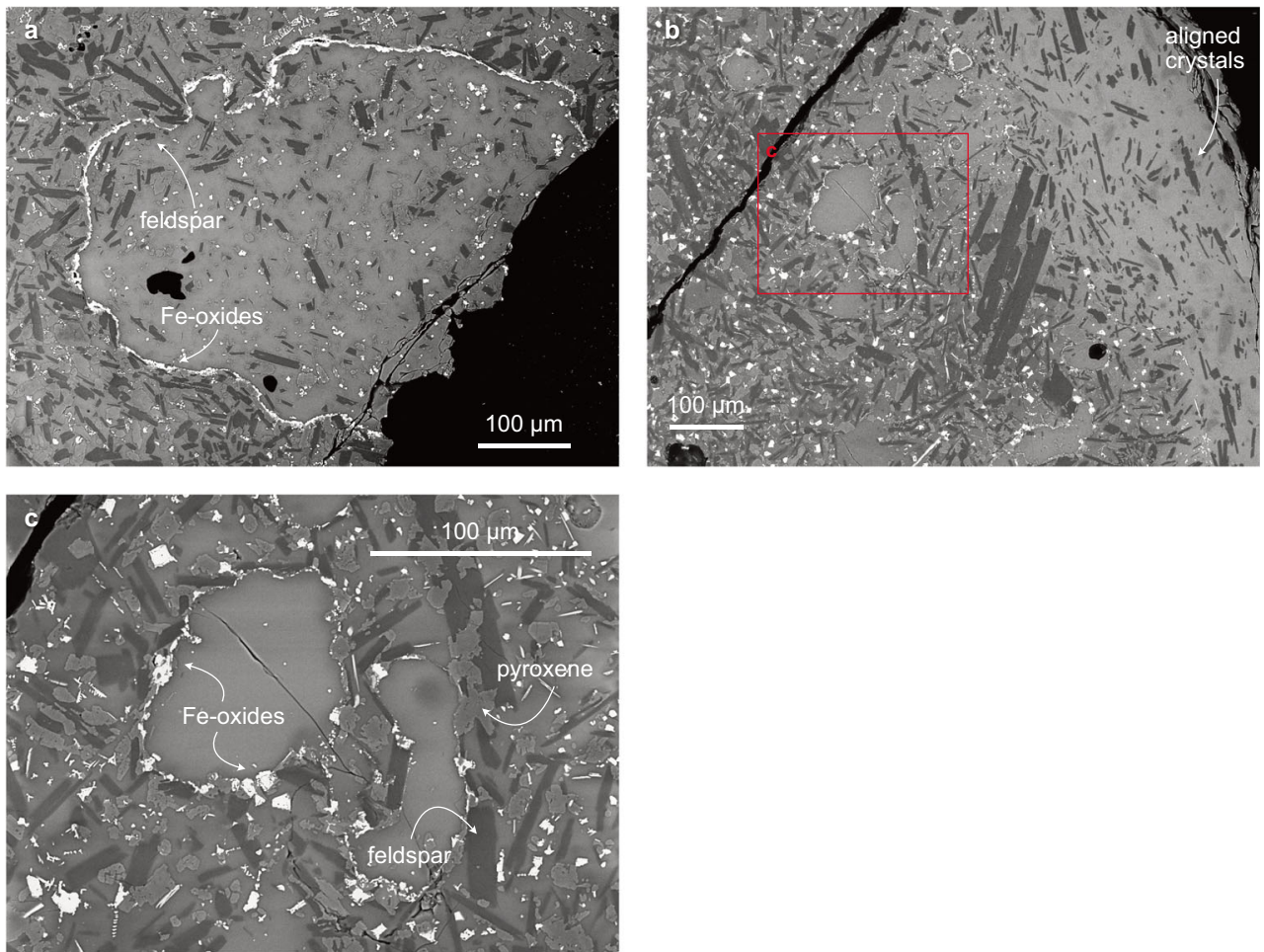
Fig. 7 Lava deltas at the $\mathrm{Pu}$ 'u 'Ō'o flow field are colored by thickness and outlined in red for areas of deposition and blue for areas of erosion. The bathymetry is shaded by slope. The $\mathrm{Pu}^{\prime} \mathrm{u} \mathbf{C}^{\circ} \mathrm{O}^{`} \overline{\mathrm{o}}$ deltas are longer and have lower slopes than those from the 2018 Kîlauea eruption. Delta identifiers are shown for comparison to Table 2. The location of large bench collapses in 2007 (E. Laeapuki) and 2016 (Kamoamoa) are indicated on the Pu'u 'O'o flow field (pink) and relative to the 2018 coastline (solid black line)

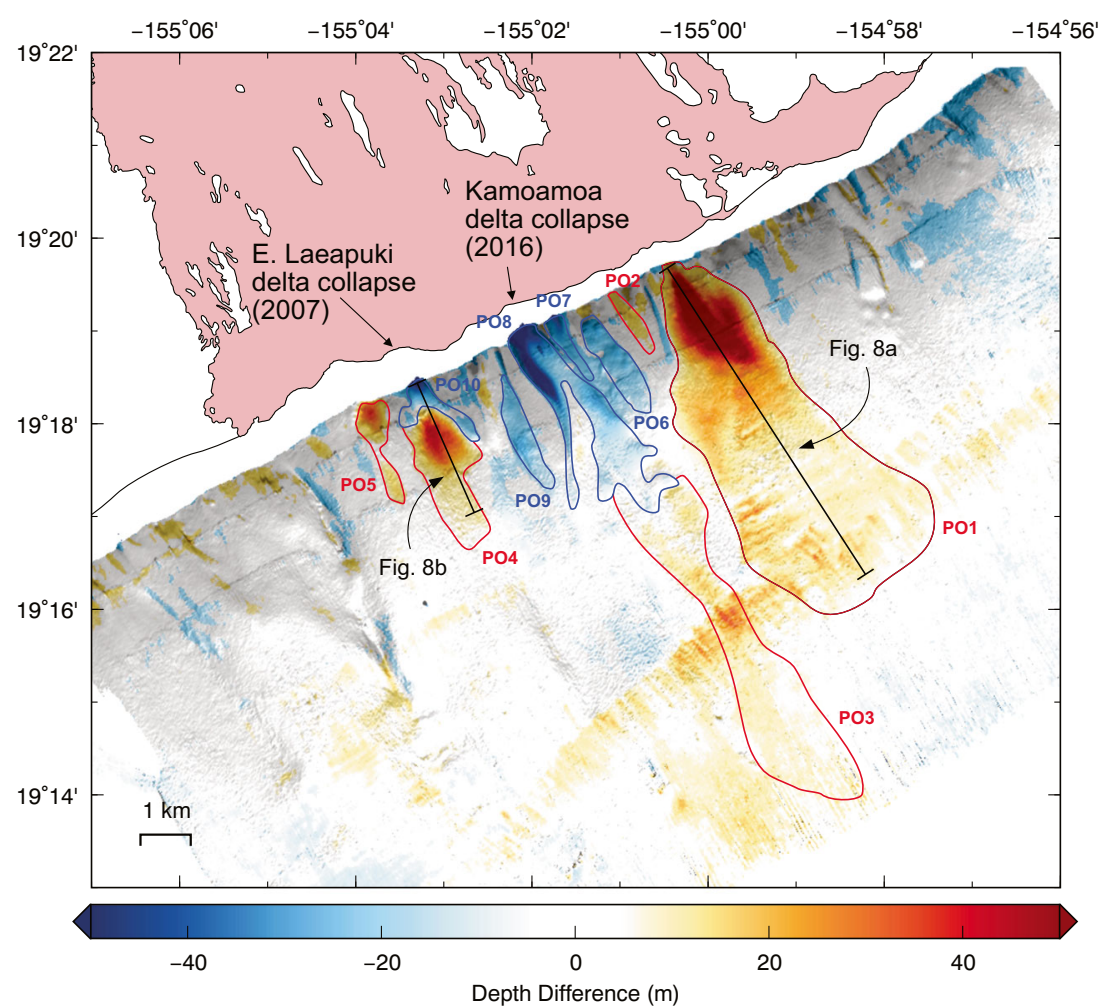

total volume of the $\mathrm{Pu}^{‘} \mathrm{u}{ }^{'} \overline{\mathrm{O}}^{‘} \overline{\mathrm{o}}$ deltas, accounting for deposition and erosion, is around $500 \times 10^{6} \mathrm{~m}^{3}$, with most deposition accounted for by the large delta at the eastern end of the flow field (Table 2). Although similar to that of the 2018 deltas, this volume represents 12 years of nearly continuous deposition or $\sim 43 \times 10^{6} \mathrm{~m}^{3}$ year $^{-1}$, a rate nearly 2 orders of magnitude smaller than that of the 2018 eruption when extrapolated to a full year $\left(>3000 \times 10^{6} \mathrm{~m}^{3}\right.$ year $\left.^{-1}\right)$.

The 15-20 $0^{\circ}$ slopes of $\mathrm{Pu}^{\prime} u^{\prime} \overline{\mathrm{O}}^{`} \overline{\mathrm{o}}$ deltas are less than those of the primary 2018 deltas. In an area of active deposition, on the east end of the $\mathrm{Pu}^{\prime} \mathrm{u}$ ' $\overline{\mathrm{O}}^{`} \overline{\mathrm{o}}$ flow field, slopes increase from 15 to $20^{\circ}$ landward. Where there are imaged collapses and downslope deposition, the resulting slopes are consistently $15^{\circ}$ (Fig. 8a,b). In contrast to the 2018 deltas, the $\mathrm{Pu}^{\prime} \mathrm{u}$ ' ${ }^{\prime}{ }^{‘} \bar{o}$ deltas maintain their pre-2006 slopes in areas of deposition. They do display decreases in slope in areas that experienced collapse post-2006, but that change converges to $\sim 15^{\circ}$ from slightly oversteepened pre-collapse slopes of around $20^{\circ}$ (Fig. 8b).

\section{Discussion}

\section{Volume of submarine deposits}

The volume of 2018 lava that was deposited in the ocean is more than half of the total erupted volume. This partitioning of subaerial to submarine lava is similar to estimates from the 1868 Mauna Loa eruption (Stearns and Macdonald 1946) as
Table $2 \mathrm{Pu}^{\text {‘ } u}$ ' $\overline{\mathrm{O}}^{`} \mathrm{o}$ Delta Properties. Italicized deltas represent areas of erosion with the corresponding depositional units in parens. Totals are net deposition and erosion and only deposition in parens

\begin{tabular}{lllc}
\hline Delta & Volume $\left(\times 10^{6} \mathrm{~m}^{3}\right)$ & Area $\left(\times 10^{5} \mathrm{~m}^{2}\right)$ & Mean thickness $(\mathrm{m})$ \\
\hline PO 1 & 302.36 & 187.25 & 16.15 \\
PO 2 & 2.96 & 3.71 & 7.96 \\
PO 3 & 54.72 & 63.76 & 8.58 \\
PO 4 & 37.09 & 33.42 & 11.1 \\
PO 5 & 9.86 & 6.78 & 14.54 \\
PO 6 & -13.68 & 12.82 & -10.67 \\
PO 7 & -6.72 & 3.53 & -19.04 \\
PO 8 (PO 3) & -60.79 & 35.05 & -17.34 \\
PO 9 & -9.25 & 7.59 & -12.2 \\
PO 10 (PO 4) & -7.66 & 5.94 & -12.91 \\
Total & $308.89(406.99)$ & $359.85(294.92)$ & \\
\hline
\end{tabular}



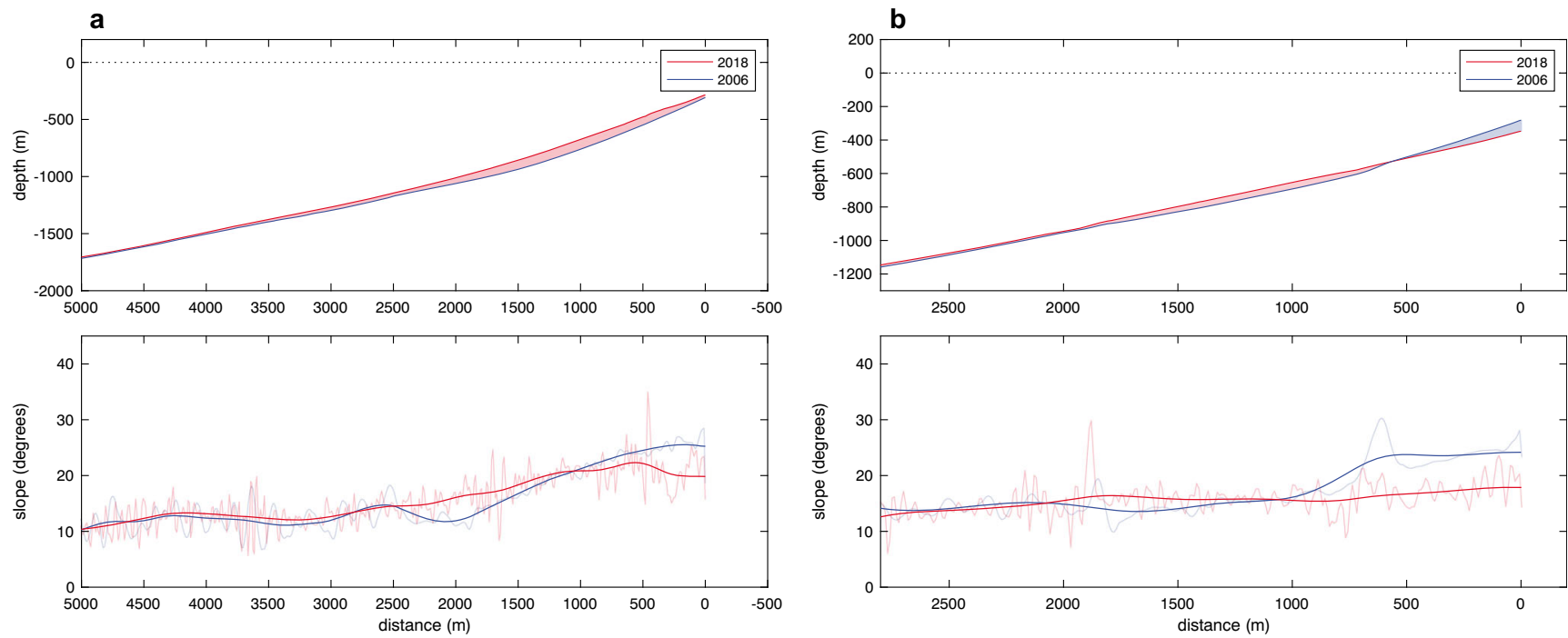

Fig. 8 Slopes along profiles for the largest $\mathrm{Pu}^{\prime} \mathrm{u}^{\prime} \overline{\mathrm{O}}^{`} \overline{\mathrm{o}}$ delta (a) and at the E. Laeapuki collapse (b). The surfaces from 2006 and 2018 are shown in blue and red respectively and areas of deposition and erosion are shown

well as the 1840 Kîlauea eruption (Kauahikaua and Trusdell 2020) and illustrates the importance of the combined subaerial and submarine records in fully understanding an eruption. Knowing the total volume of erupted lava for modern eruptions of Kîlauea is particularly important in order to link monitoring data (e.g., deformation, seismic, gravity, gas) to eruption processes. For example, in 2018, the total volume of collapse of the summit region of Kilauea was of a similar order to the total (subaerial and submarine) erupted volume (Anderson et al. 2019; Lundgren et al. 2019). Without constraints on the submarine portion, our understanding of the controls of collapse would be less complete. In addition, this eruption was the first from Kîlauea to be well-documented by UAS. These data enabled an estimate of volume flux as a function of time (Dietterich et al. 2018) that required validation by knowledge of the submarine volume.

\section{Sediment mystery}

The fine-grained sediment on the delta surface is enigmatic. Although its appearance is similar to hemipelagic mud, it is also similar to volcanic ash (Fig. 4). If it is volcanic, it could form by hydrovolcanic fragmentation at the coastline. Aerial photographs collected during this and other ocean entry eruptions commonly show a region of discolored water that has been shown to have high concentrations of fine-grained volcanic material (Sansone et al. 1991). Alternatively, the sediment could be hemipelagic mud derived from terrestrial outwash, remobilized sediment, and direct biogenic sedimentation from the water column.

Although the sediment was not sampled, we favor a volcaniclastic origin for the sediment for two reasons. First, to accumulate the observed thickness of hemipelagic mud on

by light red and blue fill. The slopes of 2006 and 2018 surfaces are shown in blue and red below with a low-pass filtered signal in saturated colors and the raw signal in faded colors

surfaces that are on the order of a month old would require unreasonably high sedimentation rates. Although one hurricane and two tropical storms passed through the region during the time of the eruption, it still seems unlikely that any remobilized material would have accumulated so quickly. Further, no ripples were observed in the sediment that would indicate current-driven resedimentation. Second, observations during the eruption showed nutrient enrichment around the eruption area that led to a chlorophyll-a anomaly (Wilson et al. 2019). Although Wilson et al. (2019) attribute the biological response to upwelling of nitrate-rich bottom water induced by lava heating, they also recognize the importance of high concentrations of silicic acid and trace metals (e.g., Mn, $\mathrm{Fe}, \mathrm{Co}$ ) that closely resemble concentrations in Kîlauea reference basalt. The ocean entry is the only viable source of ash to coastal waters in this region, and the anomalous water chemistry was well correlated with the plume of discolored water that we infer to contain high ash concentrations.

The 2018 lava deltas are dominated by coarse-grained volcanic breccias, and also contain lava flows and very finegrained ash. However, they appear to lack fine-grained (i.e., sand-sized) volcaniclasts. Fragmentation of the Kinlauea 2018 lava likely occurred through a combination of hydrovolcanic explosions and gravity-driven collapse. Routine observation indicated a general decrease in hydrovolcanic explosions relative to $\mathrm{Pu}^{\prime} \mathrm{u}$ ' $\overline{\mathrm{O}}^{`} \bar{o}$ ocean entries of the past. This may explain the dominance of volcanic breccias relative to ash as well as the apparent lack of fine-grained volcaniclasts.

The reduced intensity of hydrovolcanic explosions during 2018 may reflect less efficient mixing of seawater and lava (Zimanowski et al. 1997) than at $\mathrm{Pu}^{\prime} u{ }^{\prime} \overline{\mathrm{O}}^{`} \bar{o}$ ocean entries, which could be attributed to differences in viscosity, temperature, and higher volume flux across the coastline. All of these 
factors would make it more difficult to obtain efficient mixing of seawater and lava. In particular, our volume estimates indicate that the average flux to the oceans for the 2018 eruption was more than an order of magnitude higher than at $\mathrm{Pu} \mathrm{u}^{\prime} \mathrm{u}{ }^{\prime} \overline{\mathrm{O}}^{`} \overline{\mathrm{o}}$, which would significantly reduce the residence time of lava at the land-water interface where mixing occurs. In addition, $\mathrm{Pu}^{\prime} \mathrm{u}$ ' $\overline{\mathrm{O}}^{`} \overline{\mathrm{o}}$ lava flows that reached the coastline were commonly aphyric and subject to quench fragmentation as opposed to the 2018 flows that were highly crystalline when they reached the coast. As a result, it is more likely for 2018 lava to cross the coastline as lava flows that remain intact as they flow down the submarine flank (Fig. 4e), or gravitationally break apart into blocks aided by seawater quenching.

\section{Slope stability}

The stability of newly formed lava deltas and the mechanisms by which they fail are not well known (Poland and Orr, 2014). The deltas formed by the 2018 eruption and the $\mathrm{Pu}^{6} \mathrm{u}$ ' $\overline{\mathrm{O}}^{`} \overline{\mathrm{o}}$ eruption offer a unique view of contrasting styles of deposition and the potential for failure. The 2018 deltas formed from high flux ' $a$ 'a flows and produced steep deltas with nearshore slopes up to $35^{\circ}$. The newly formed delta slopes are uniformly steeper than those that were present prior to the eruption by up to $10-15^{\circ}$ (Figs. 3 and 9). These slopes are built outwards from the pre-eruption coastline to distances of 1.5 to $2 \mathrm{~km}$. In contrast, the $\mathrm{Pu}^{6} \mathrm{u}$ ' $\mathrm{O}^{`} \overline{\mathrm{o}}$ deltas (between 2006 and 2018) formed from low-flux pāhoehoe flows and produced deltas that extend up to $7 \mathrm{~km}$ from the coastline. Their slopes of $10-20^{\circ}$ experienced limited change in slope over the last decade despite the continued input of lava (Figs. 8 and 9). The Nesjharun flows in Iceland, which entered a lake, also produced deltas with low slopes, but were interpreted to have mantled the pre-existing low-slope lakebed (Stevenson et al. 2012). To determine if pre-existing slopes were appreciably lower at the $\mathrm{Pu}^{6} \mathrm{u}$ ' $\overline{\mathrm{O}}^{`} \overline{\mathrm{o}}$ delta site relative to the 2018 delta site, we examined single-beam bathymetric surveys conducted by NOAA in 1980. Although these data do not provide the same accuracy as modern multibeam surveys, we have high confidence in their internal consistency and thus are useful for comparing the two sites. The slopes derived from these data vary as a function of depth and lie between 15 and $40^{\circ}$ over the first $1000 \mathrm{~m}$ of depth for both $\mathrm{Pu}^{\prime} \mathrm{u}$ ' $\overline{\mathrm{O}}^{`} \overline{\mathrm{o}}$ and the 2018 delta sites with little difference between the two (Supplementary Figure 4). This suggests that the modern slopes are not strongly influenced by the pre-existing shape of the submarine volcano flanks and instead result from the inherent properties of the material that has deposited hundreds of meters thick deltas at each location.

The gross morphology of the deltas may also reflect processes of sediment redistribution via landslides. The $\mathrm{Pu}$ ' $\mathrm{u}$ ' $\overline{\mathrm{O}}^{`} \overline{\mathrm{o}}$ deltas experienced dozens of landslides that were recognized by bench collapses at the coastline (Poland and Orr 2014; Hawaiian Volcano Observatory 2020) and many more
Fig. 9 Heat maps of slope as function of depth for the same areas in 2006 (green) and 2018 (blue) bathymetric data within the largest mapped delta regions from the 2018 Killauea eruption (top row) and $\mathrm{Pu}^{\prime} \mathrm{u}{ }^{`} \overline{\mathrm{O}}^{`} \mathrm{o}$ area (bottom row). The colorbars indicate the frequency (i.e., number of pixels) within a given depth and slope bin. The Kapoho delta area was transformed from a relatively smoothly decreasing slope with depth before the eruption to a near uniform slope between 30 and $35^{\circ}$ over the width of the delta after the eruption. Despite differences in data quality at the $\mathrm{Pu}^{\prime} \mathrm{u}$ ' $\overline{\mathrm{O}}^{`} \overline{\mathrm{o}}$ region, the dominant slopes remain unchanged, with a slope of $10-15^{\circ}$ at depths > $1000 \mathrm{~m}$ and increasing slightly towards the coastline
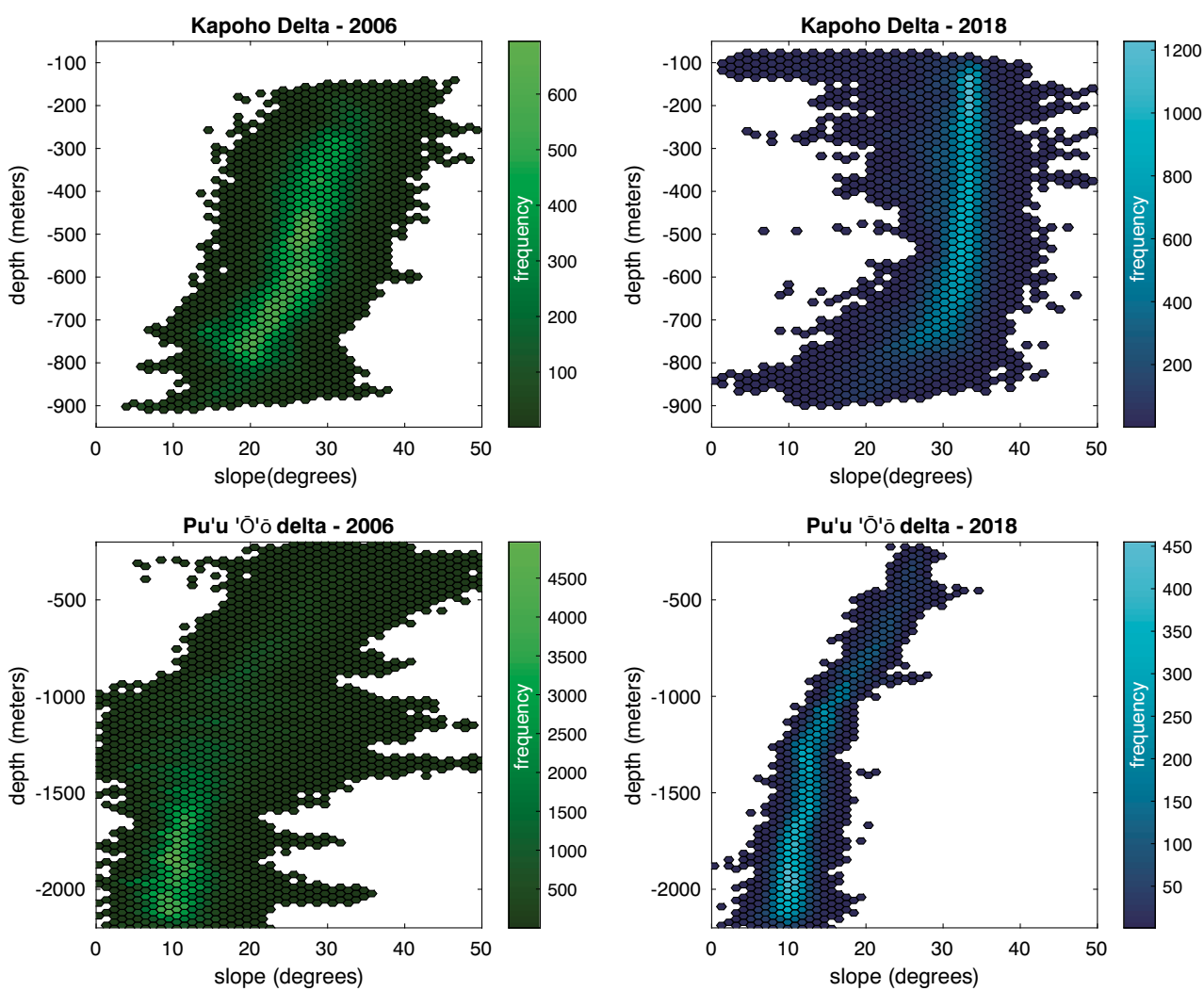
that were identified from hydrophones deployed at Lō'ihi (Caplan-Auerbach et al. 2001). Several documented failures of the $\mathrm{Pu}^{\prime} \mathrm{u}{ }^{\prime} \overline{\mathrm{O}}^{`} \overline{\mathrm{o}}$ delta that have occurred since 2006 are imaged by the new bathymetric surveys (Fig. 7). These failures occurred in slightly oversteepened slopes $\left(\sim 20^{\circ}\right)$ that evolved towards a slope consistent with the rest of the deltas $\left(\sim 15^{\circ}\right)$ after failure (Fig. 8b). Bathymetric mapping shows that the material mobilized in these collapses is deposited on the submarine slopes $5-10 \mathrm{~km}$ from the coastline. In contrast, no large-scale failures of the 2018 deltas have been documented by deployed hydrophones or by coastal bench collapses so far. At $\mathrm{Pu}^{\prime} \mathrm{u}{ }^{\prime} \overline{\mathrm{O}}^{`} \mathrm{o}$, most slope failures have occurred during periods of active lava emplacement, suggesting that oversteepening of the slope due to active deposition is a primary driver for failure. If this is true, the lack of large failures of the 2018 deltas, even with much steeper slopes and more rapid delivery of delta material, is surprising.

\section{Mechanistic model}

We propose a mechanistic model to explain the differences in morphology between the $\mathrm{Pu}^{\prime} \mathrm{u}$ ' $\bar{O}^{`} \bar{o}$ and 2018 Kilauea delta systems and the apparently greater stability of the 2018 deltas. Included in the model are the static friction that controls the steepest achievable slope of the material, the dynamic friction that governs the slope attained during small-scale mass movement (i.e., angle of repose), and fluidized flow resulting from larger-scale mass movement. We suggest that differences in materials that make up the deltas can account for the differences in both the apparent stability and morphology (e.g., slope and length) of the 2018 and $\mathrm{Pu}^{\prime} \mathrm{u}{ }^{\prime} \overline{\mathrm{O}}^{`} \overline{\mathrm{o}}$ delta slopes. Although comprehensive surveys of delta material have not been conducted, our observations indicate that the 2018 deltas are dominated by volcanic breccia with cobble- to bouldersized fragments as well as intact lava flows (Figs. 4, 10), consistent with previous observations of the shallow submarine portion of 'a'a flows (Moore et al. 1973). This contrasts with observations of $\mathrm{Pu}^{\prime} u$ ' $\overline{\mathrm{O}}^{`} \overline{\mathrm{o}}$ deltas that contain a large proportion of fine-grained volcaniclastic material (i.e., hyaloclastite) (Tribble, 1991; Sansone and Smith, 2006), which are consistent with ancient Hawaiian delta deposits (Schiffman et al. 2006). We suggest that this difference in grain size reflects differences in the efficiency of fragmentation at the coastline (Fig. 10). Pāhoehoe flows, with lower viscosity, higher temperature, and lower flux promote more efficient fragmentation by hydrovolcanic explosions and quench granulation with finer grain sizes than ' $a$ 'ā flows. It follows that ' $a$ 'a flows would more commonly produce intact flows that move along the submarine slopes. We observed evidence of this on the 2018 deltas via direct observation and through delta morphology. In addition, we observed hydrothermal fluid circulation in the area of intact flows (Fig. 4), but not elsewhere, indicating that flows are an effective means to advect heat down the submarine slope. Previous studies have noted small lava flows on pāhoehoe deltas (Tribble 1991), but delta morphology suggests that they are less

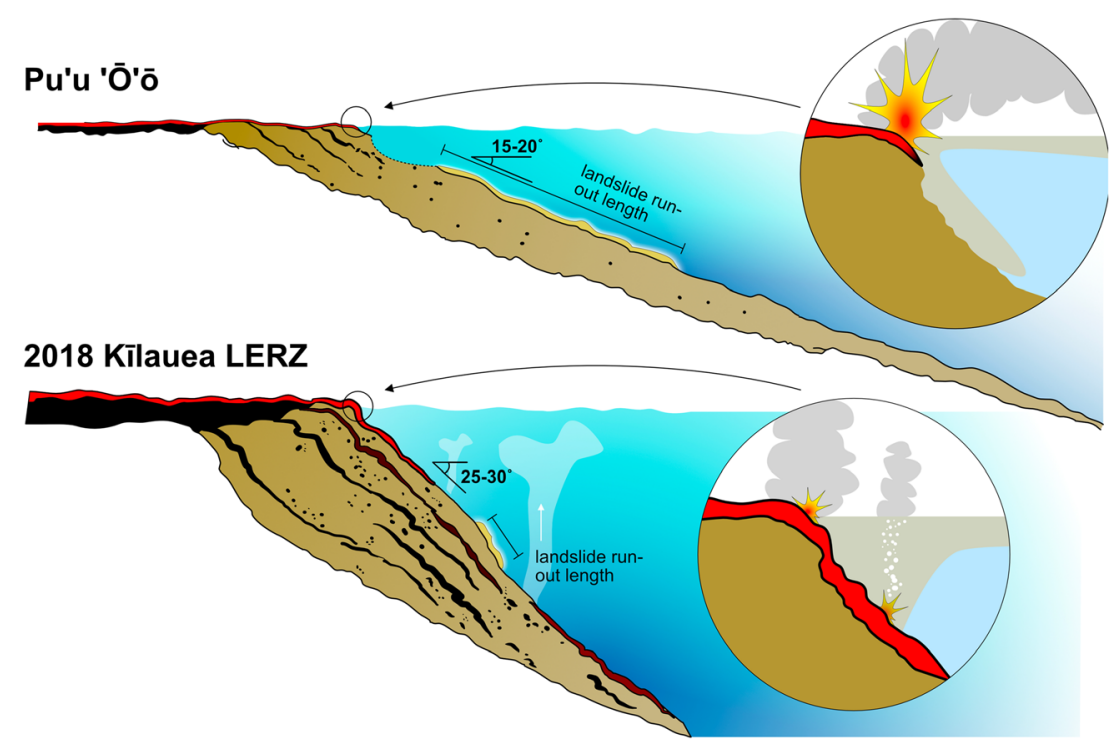

Fig. 10 Comparison of primary features of $\mathrm{Pu}^{\prime} \mathrm{u}{ }^{`} \overline{\mathrm{O}}^{`} \overline{\mathrm{o}}$-type (low-flux) and 2018-type (high-flux) ocean entries and resulting deltas. At the low-flux delta, which is characterized by efficient fragmentation (larger and more frequent hydrovolcanic explosions, quench granulation), delta lengthening occurs primarily by grain flow. The resulting deltas are lower slope and longer due to large volume, long run-out landslides. The high-flux delta, characterized by inefficient fragmentation at the coastline, leads to more deposition by lava flows and volcanic breccias due to gravitational collapse of flows. The larger grain size limits the run-out length of landslides resulting in higher slopes, close to the angle of repose. The greater advection of heat into the shallow ocean by high-flux deltas produces upwelling (Wilson et al. 2019) that, along with alteration of suspended ash, fertilizes the upper ocean. Fewer and smaller hydrovolcanic explosions at the coastline limit the production of fine-grained clastic material 
common. In both cases, the deltas are dominated by clastic material.

The steepest stable slope of a pile of unconsolidated clastic material depends on the static friction, which is controlled by the grain size, shape, packing, and surface roughness (Carrigy 1970). The relation among these parameters is empirically determined and although the effects of water and gravity have been explored, they are generally considered minor (Kleinhans et al. 2011). In addition, the grain size variations across the $\mathrm{Pu}^{\prime} \mathrm{u}$ ' $\mathrm{O}^{`} \overline{\mathrm{o}}$ and 2018 deltas (i.e., sand to boulder) are larger than is typically examined within any individual empirical study. However, there is general agreement that static friction and angle of repose increases with increasing grain size. For coarse-grained material, studies of rip-rap suggest angles of repose of 34-38 for subangular clasts (Froehlich 2011). Studies of finer-grained material suggest angles of 30 $34^{\circ}$ (Carrigy 1970). Although empirical models, such as those cited, may not be directly applicable to the lava deltas, it is apparent that the slope of the 2018 Killauea deltas is at least near their predicted angle of repose whereas the slope of the $\mathrm{Pu}^{6} \mathrm{u}$ ' $\overline{\mathrm{O}}^{`} \overline{\mathrm{o}}$ deltas is below what would be predicted based on grain size alone.

Another potential control on the observed delta slopes may arise from the dynamic friction that dominates grains in motion. Grains in motion are assumed to have fewer points of contact and thus reduced friction and shallower angles of repose. Experimental studies find decreases of 10 to $20 \%$ in the dynamic relative to static angle of repose independent of grain size (Kleinhans et al. 2011; Cheng and Zhao 2017). Both delta systems display evidence for downslope mass transport. On the 2018 deltas, highly sorted bands of breccia-oriented downslope (Fig. 4b,c) indicate ubiquitous, small landslides. Although the downslope dimensions are not constrained, their widths are on the order of $10 \mathrm{~m}$. At the $\mathrm{Pu}^{\prime} \mathrm{u}$ ' $\overline{\mathrm{O}}^{`} \bar{o}^{\mathrm{o}}$ deltas, much larger landslides have occurred and distributed material several kilometers downslope. In addition, hydroacoustic data collected during a 3-month interval in 1998 indicate that there are many (4-10 per day during) smaller mass movements of delta material on the $\mathrm{Pu}^{\prime} \mathrm{u}$ ' $\mathrm{O}^{\prime} \bar{o}$ deltas (Caplan-Auerbach et al. 2001). The dynamic angle of repose is perhaps a better fit for the observed slope on the 2018 deltas; however, this reduction is not sufficient to explain the much shallower slope of the $\mathrm{Pu}^{\prime} \mathrm{u}$ ' $\mathrm{O}^{‘} \mathrm{o}$ deltas.

The low slopes of the $\mathrm{Pu}^{`} \mathrm{u}{ }^{`} \overline{\mathrm{O}}^{`} \overline{\mathrm{o}}$ deltas may be explained by the integrated effects of fluidized flow of delta material. Submarine landslides have been documented to travel tens of kilometers on very low slopes (Masson et al. 2006). Despite a similar magnitude of volcanic deposition at both delta systems, if landslides distribute material farther at the $\mathrm{Pu}^{\prime} \mathrm{u}$ ' $\overline{\mathrm{O}}^{`} \overline{\mathrm{o}}$ deltas, they would evolve towards shallower slopes. A model system that has been successful in predicting controlled granular flow experiments was presented by Iverson and Denlinger (2001). In this model, Coulomb (i.e., frictional) forces between grains are averaged over the thickness of the landslide. A number of factors control the magnitude of frictional forces, but the frequency of grain collisions is the most significant. This model recognizes the importance of internal pore pressure in controlling those collisions and identifies a parameter D (diffusivity) that indicates the rate at which pore pressure dissipates. D depends on the viscosity of the suspending fluid, which may increase with an increasing proportion of silt-size and smaller particles, and the grain size and stiffness of the suspension, which controls the porosity and Young's modulus of the suspension. Assuming no difference in the viscosity of the suspending fluid between, smaller grain sizes - as inferred for the $\mathrm{Pu}^{6} \mathrm{u}$ ' $\overline{\mathrm{O}}^{`} \overline{\mathrm{o}}$ deltas — will lead to lower $\mathrm{D}$, thus greater pore pressure and decreased Coulomb forces. As a result, we would expect $\mathrm{Pu}^{\prime} \mathrm{u}$ ' $\overline{\mathrm{O}}^{`} \overline{\mathrm{o}}$ delta collapses to result in longer run-out than 2018 delta collapses (Fig. 10), where large grain size and high porosity would cause pore pressure to dissipate very rapidly, increasing grain-to-grain collisions that would cause flows to stop sooner and in accord with empirical estimates of the dynamic angle of repose. This difference in grain size between the two delta systems is analogous to the toe and levees of debris flows where mechanical sorting leads to larger grain sizes and greater resistance to flow (Iverson and Denlinger 2001).

Systematically longer run-out lengths would result in the $\mathrm{Pu}^{6} \mathrm{u}$ ' $\overline{\mathrm{O}}^{\prime} \overline{\mathrm{o}}$ deposits evolving towards longer deltas with shallower slopes than the 2018 deltas (Fig. 10). However, an additional contribution to delta morphology might be the frequency and size of landslide events. Although there is evidence of abundant landslides on both deltas in the form of observations of well-sorted runnels on the 2018 deltas and hydroacoustic data from the $\mathrm{Pu}^{\prime} u$ ' $\overline{\mathrm{O}}^{`} \overline{\mathrm{o}}$ deltas, the $\mathrm{Pu}^{\prime} \mathrm{u}$ ' $\overline{\mathrm{O}}^{`} \overline{\mathrm{o}}$ deltas have experienced large collapses, and the 2018 delta has not (Caplan-Auerbach et al. 2019). One possible explanation for this is an increased proportion of lava flows within the 2018 deltas that may act to stabilize and strengthen the deposits and perhaps limit the size of failures. A similar model was suggested for the submarine slopes of Mauna Loa (Garcia and Davis 2001), although others have suggested the presence of intercalated lava flows in delta deposits might decrease stability with flow tops providing a conduit for overpressured fluids (Schiffman et al. 2006). As the slopes of the Killauea 2018 deltas at $\sim 30^{\circ}$ are roughly similar to that expected for coarse-grained clastic deposits, it would appear that stabilizing or destabilizing effects of intercalated lava flows are secondary to the effects of grain size.

\section{Conclusions}

Our study illustrates the value in rapid-response seafloor mapping to quantify the total volume output of an eruption with lava flows that reach the coastline. Such data are essential to 
linking the properties of an eruption with its geophysical signals during a volcanic crisis and aid models of volcano behavior that inform associated hazard assessments. In addition, our study utilized new bathymetric mapping and ROV observations to evaluate the physical characteristics of the lava deltas formed during two Kîlauea eruptions, in 2018, as well as those formed at $\mathrm{Pu}^{\prime} \mathrm{u}$ ' ${ }^{\circ} \overline{\mathrm{o}}^{`} \mathrm{o}$ between 2006 and 2018. These two delta systems formed from distinctly different eruption types and produced deltas with markedly different morphology. The key conclusions of our study include:

- The volume of the 2018 lava deltas, $\sim 760 \times 10^{6} \mathrm{~m}^{3}$, is more than $60 \%$ of the total erupted volume. The total erupted volume provides insight into the physical processes of eruption (e.g., link to caldera collapse). Total eruption volumes that include submarine deposits are typically not documented.

- The 2018 deltas contain a minor component of volcanic ash, coarse volcanic breccia, and lava flows the latter of which extend, intact, up to $2 \mathrm{~km}$ from the pre-eruption coastline and descend to water depths of $\sim 700 \mathrm{~m}$. The coarse average grain size, relative to $\mathrm{Pu}^{\prime} \mathrm{u}{ }^{\prime} \overline{\mathrm{O}}^{‘} \overline{\mathrm{o}}$ and ancient Hawaiian deltas, is consistent with diminished hydrovolcanic fragmentation (e.g., explosion, quench granulation) due to high-volume flux across the coastline and the cooler and more viscous nature of the 2018 lava.

- $\mathrm{Pu}^{\prime} u$ ' $\overline{\mathrm{O}}^{`} \mathrm{o}$ deltas can produce large, highly-mobile landslides that we suggest are due to their finer grain size, which enables the flow to support and maintain high pore pressure modulating inter-particle friction. The 2018 deltas, in contrast and due to their large grain size, can only produce grain-supported flows that are significantly less mobile, limiting down-slope transport.

- Differences in the material properties and mode of downslope transport result in distinct differences in slope with $\mathrm{Pu}^{\prime} \mathrm{u}$ ' $\overline{\mathrm{O}}^{`} \mathrm{o}$ deltas supporting $15-20^{\circ}$ slopes, reflecting long run-out landslides, and 2018 Kīlauea deltas supporting $30-35^{\circ}$ slopes, reflecting static or dynamic friction.

Our results suggest that the propensity for large collapses on lava deltas is linked to the grain size of the delta, which is controlled by the efficiency of fragmentation at the coastline. Additional study is required to validate this hypothesis including continued post-eruption monitoring of the evolution of both the $\mathrm{Pu}^{\prime} u$ ' $\bar{O}^{‘} \bar{o}$ and 2018 lava deltas, direct observations and sampling over both deltas, and experimental and numerical studies of delta slope stability. If borne out, observations of the efficiency of fragmentation at the coastline could provide a new tool to evaluate the hazards posed by lava delta collapse during the next volcanic crisis in Hawaii and at other volcanic islands.

Supplementary Information The online version contains supplementary material available at https://doi.org/10.1007/s00445-020-01424-1.
Acknowledgments The authors wish to thank the National Science Foundation for support of this project (NSF OCE-0525863) and the National Oceanographic and Atmospheric Administration Office of Ocean Exploration and Research for support of the ship and ROV time. We thank the Ocean Exploration Trust for conducting at-sea operations with E/V Nautilus and ROV Hercules. We thank Larry Mayer and Erin Heffron for assistance with data collection and processing and Darlene Lim and Chris German for sharing vessel and vehicle time. We thank Pete Dawson and Mike Rhodes at the Gilmore XRF laboratory for assisting with geochemical analyses. We greatly appreciate manuscript review and comments from Jim Kauahikaua, Tim Orr, Matt Patrick, and Ian Skilling. We also commend the NOAA Office of Coast Survey and NCEI for making historic bathymetric surveys findable and accessible in their archive.

Code availability N/A

\section{Authors' contributions N/A}

Funding Support for this research was provided by the National Science Foundation OCE-0525863, Ship and ROV support was provided by NOAA Office of Ocean Exploration.

Data availability Bathymetry data are available at www.mgds.org and ROV dive video and samples are archived at the University of Rhode Island by the Ocean Exploration Trust.

\section{Compliance with ethical standards}

\section{Conflict of interest N/A}

Open Access This article is licensed under a Creative Commons Attribution 4.0 International License, which permits use, sharing, adaptation, distribution and reproduction in any medium or format, as long as you give appropriate credit to the original author(s) and the source, provide a link to the Creative Commons licence, and indicate if changes were made. The images or other third party material in this article are included in the article's Creative Commons licence, unless indicated otherwise in a credit line to the material. If material is not included in the article's Creative Commons licence and your intended use is not permitted by statutory regulation or exceeds the permitted use, you will need to obtain permission directly from the copyright holder. To view a copy of this licence, visit http://creativecommons.org/licenses/by/4.0/.

\section{References}

Anderson KR, Johanson IA, Patrick MR, Gu M, Segall P, Poland MP, Montgomery-Brown EK, Miklius A (2019) Magma reservoir failure and the onset of caldera collapse at Kîlauea volcano in 2018. Science 366(6470):eaaz1822. https://doi.org/10.1126/science.aaz1822

Bosman A, Casalbore D, Romagnoli C, Chiocci FL (2014) Formation of an 'a'à lava delta: insights from time-lapse multibeam bathymetry and direct observations during the Stromboli 2007 eruption. Bull Volcanol 76(7):173. https://doi.org/10.1007/s00445-014-0838-2

Caplan-Auerbach J, Fox CG, Duennebier FK (2001) Hydroacoustic detection of submarine landslides on Kilauea volcano. Geophys Res Lett 28(9):1811-1813. https://doi.org/10.1029/2000gl012545

Caplan-Auerbach J, Dziak RP, Bohnenstiehl DR, Chadwick WW, Lau TK (2014) Hydroacoustic investigation of submarine landslides at West Mata volcano. Lau Basin:1-8. https://doi.org/10.1002/(issn) 1944-8007 
Caplan-Auerbach, J., Shen, Y., Morgan, J., Soule, S. A. (2019). Hydroacoustic recordings of lava-water interactions and landslides during the 2018 eruption of Kilauea volcano. AGU Fall Meeting, Abstract V14A-01

Caress DW, Clague DA, Paduan JB, Martin JF, Dreyer BM, Chadwick WW, Denny A, Kelley DS (2012) Repeat bathymetric surveys at 1metre resolution of lava flows erupted at axial seamount in April 2011. Nat Geosci 5(7):483-488. https://doi.org/10.1038/ngeo1496

Carey R, Soule SA, Manga M, White JD, McPhie J, Wysoczanski R, Jutzeler M, Tani K, Yoerger D, Fornari D (2018) The largest deepocean silicic volcanic eruption of the past century. Sci Adv 4(1): e1701121

Carrigy MA (1970) Experiments on the angles of repose of granular materials. Sedimentology 14(3-4):147-158. https://doi.org/10. 1111/j.1365-3091.1970.tb00189.x

Cashman KV, Thornber C, Kauahikaua JP (1999) Cooling and crystallization of lava in open channels, and the transition of Pāhoehoe lava to 'A'ā. Bull Volcanol 61(5):306-323. https://doi.org/10.1007/ s004450050299

Chadwick WW, Embley RW (1995) SeaBeam depth changes associated with recent lava flows, CoAxial segment, Juan de Fuca Ridge: evidence for multiple eruptions between 1981-1993. Geophys Res Lett 22(2):167-170. https://doi.org/10.1029/94gl01895

Chadwick WW, Embley RW, Fox CG (1991) Evidence for volcanic eruption on the southern Juan de Fuca Ridge between 1981 and 1987. Nature 350(6317):416-418. https://doi.org/10.1038/ $350416 \mathrm{a} 0$

Chadwick, W. W., Wright, I. C., Schwarz-Schampera, U., Hyvernaud, O., Reymond, D., deRonde, C. E. J. (2008). Cyclic eruptions and sector collapses at Monowai submarine volcano, Kermadec arc: 1998-2007. Geochemistry, geophysics, Geosystems, 9(10). https:// doi.org/10.1029/2008gc002113

Chadwick WW, Dziak RP, Haxel JH, Embley RW, Matsumoto H (2011) Submarine landslide triggered by volcanic eruption recorded by in situ hydrophone. Geology 40(1):51-54. https://doi.org/10.1130/ g32495.1

Cheng N-S, Zhao K (2017) Difference between static and dynamic angle of repose of uniform sediment grains. International Journal of Sediment Research 32(2):149-154. https://doi.org/10.1016/j.ijsrc. 2016.09.001

Chiocci FL, Romagnoli C, Bosman A (2008) Morphologic resilience and depositional processes due to the rapid evolution of the submerged Sciara del Fuoco (Stromboli Island) after the December 2002 submarine slide and tsunami. Geomorphology 100(3):356-365. https:// doi.org/10.1016/j.geomorph.2008.01.008

Deardorff N, Cashman K (2017) Rapid crystallization during recycling of basaltic andesite tephra: timescales determined by reheating experiments. Sci Rep 7(1):46364. https://doi.org/10.1038/srep46364

Dietterich, H. R., Patrick, M. R., Diefenbach, A. K., Parcheta, C., Lev, E., Folks, N. L. (2018). Lava flow hazard modeling and the assessment of effusion rates and topographic change with UAS and lidar during the 2018 Kilauea lower East Rift Zone eruption. American Geophysical Union, Abstract \#V21B-03

Dobran F, Papale P (1993) Magma-water interaction in closed systems and application to lava tunnels and volcanic conduits. Journal of Geophysical Research: Solid Earth 98(B8):14041-14058. https:// doi.org/10.1029/93jb00437

Finch RH, Macdonald GA (1955) Hawaiian volcanoes during 1950. In: Contributions to general geology 1951-1954. USGS, Washington, DC, pp 27-89. https://doi.org/10.3133/b996b

Fisher RV (1960) Classification of volcanic breccias. Bull Geol Soc Am 71(7):973-982. https://doi.org/10.1130/0016-7606(1960)71(973: covb)2.0.co;2

Friant AL, Deplus C, Boudon G, Feuillet N, Trofimovs J, Komorowski JC, Sparks RSJ, Talling P, Loughlin S, Palmer M, Ryan G (2010) Eruption of Soufrière Hills (1995-2009) from an offshore perspective: insights from repeated swath bathymetry surveys. Geophys Res Lett 37(19). https://doi.org/10.1029/2010g1043580

Froehlich DC (2011) Mass angle of repose of open-graded rock riprap. J Irrig Drain Eng 137(7):454-461. https://doi.org/10.1061/(asce)ir. 1943-4774.0000316

Gansecki C, Lee RL, Shea T, Lundblad SP, Hon K, Parcheta C (2019) The tangled tale of Kilauea's 2018 eruption as told by geochemical monitoring. Science 366(6470):eaaz0147. https://oi.org/10.1126/ science.aaz0147

Garcia MO, Davis MG (2001) Submarine growth and internal structure of ocean island volcanoes based on submarine observations of Mauna Loa volcano, Hawaii. Geology 29(2):163. https://doi.org/10.1130/ 0091-7613(2001)029<0163:sgaiso>2.0.co;2

German, C. R., Lim, D. S. S., Brier, J. A., Huber, J. A., Nawotniak, S. K., Shock, E., Raineault, N. (2018). Time series study of hydrothermal venting at Lo'ihi seamount following the 2018 Kilauea eruption. AGU Fall Meeting, Abstract V14A-07

Hawaiian Volcano Observatory (2020) Preliminary analysis of hazards at the Kamokuna ocean entry, in preliminary analysis of volcanic hazards at Kilauea volcano, Hawai' $i, 2017-2018$, eds. Neal, C.A. and Anderson, K.R., USGS Open File Report 2020-1002, Reston, VA: USGS, 3-12

Iverson RM, Denlinger RP (2001) Flow of variably fluidized granular masses across three-dimensional terrain: 1 . Coulomb mixture theory. Journal of Geophysical Research: Solid Earth 106(B1):537-552. https://doi.org/10.1029/2000jb900329

Jones JG, Nelson PHH (1970) The flow of basalt lava from air into water - its structural expression and stratigraphic significance. Geol Mag 107(1):13-19. https://doi.org/10.1017/s0016756800054649

Kauahikaua J, Cashman KV, Mattox TN, Heliker CC, Hon KA, Mangan MT, Thornber C (1998) Observations on basaltic lava streams in tubes from Kilauea volcano, island of Hawai'i. Journal of Geophysical Research: Solid Earth 103(B11):27303-27323. https://doi.org/10.1029/97jb03576

Kauahikaua, J. P., Trusdell, F. A. (2020). Have humans influenced volcanic activity on the lower east rift zone of Kilauea volcano? A publication review (Open-File Report 2020-1017) (p. 15)

Kleinhans MG, Markies H, deVet SJ, intVeld, A. C., Postema, F. N. (2011) Static and dynamic angles of repose in loose granular materials under reduced gravity. J Geophys Res 116(E11):95-13. https:// doi.org/10.1029/2011je003865

Lundgren PR, Bagnardi M, Dietterich H (2019) Topographic changes during the 2018 Kîlauea eruption from single-pass airborne InSAR. Geophys Res Lett 46(16):9554-9562. https://doi.org/10. 1029/2019g1083501

Masson, D. G., Harbitz, C. B., Wynn, R. B., Pedersen, G., Løvholt, F. (2006). Submarine landslides: processes, triggers and hazard prediction. philosophical transactions. Series A, Mathematical, Physical, and Engineering Sciences, 364(1845), 2009-2039. https://doi.org/ $10.1098 /$ rsta.2006.1810

Mattox TN, Mangan MT (1997) Littoral hydrovolcanic explosions: a case study of lava-seawater interaction at Kilauea volcano. J Volcanol Geotherm Res 75(1-2):1-17. https://doi.org/10.1016/ s0377-0273(96)00048-0

Moore JG, Ault WU (1965) Historic littoral cones in Hawaii. Pac Sci 19: $3-11$

Moore JG, Cristolfini R, LoGiudice A (1971) Development of pillows on the submarine extension of recent lava flows, Mount Etna, Sicily. USGS Professional Paper 750:89-97

Moore JG, Phillips RL, Grigg RW, Peterson DW, Swanson DA (1973) Flow of lava into the sea, 1969-1971, Kilauea volcano, Hawaii. Geol Soc Am Bull 84:537-546. https://doi.org/10.1130/00167606(1973)84

Moore JG, Normark WR, Holcomb RT (1994) Giant Hawaiian landslides. Annual Reviews of Earth and Planetary Science 22:119-144 
Neal, C. A., Anderson, K. R. (2020). Preliminary analyses of volcanic hazards at Kīlauea volcano, Hawai'i, 2017-2018, USGS Open File Report 2020-1002, Reston, VA: USGS

Neal CA, Brantley SR, Antolik L, Babb JL, Burgess M, Calles K, Cappos M, Chang JC, Conway S, Desmither L, Dotray P, Elias T, Fukunaga P, Fuke S, Johanson IA, Kamibayashi K, Kauahikaua J, Lee RL, Pekalib S, Miklius A, Million W, Moniz CJ, Nadeau PA, Okubo P, Parcheta C, Patrick MR, Shiro B, Swanson DA, Tollett W, Trusdell F, Younger EF, Zoeller MH, Montgomery-Brown EK, Anderson KR, Poland MP, Ball JL, Bard J, Coombs M, Dietterich HR, Kern C, Thelen WA, Cervelli PF, Orr T, Houghton BF, Gansecki C, Hazlett R, Lundgren P, Diefenbach AK, Lerner AH, Waite G, Kelly P, Clor L, Werner C, Mulliken K, Fisher G, Damby D (2019) The 2018 rift eruption and summit collapse of Killauea volcano. Science 363(6425):367-374. https://doi.org/10.1126/science. aav7046

Patrick MR, Dietterich HR, Lyons JJ, Diefenbach AK, Parcheta C, Anderson KR, Namiki A, Sumita I, Shiro B, Kauahikaua JP (2019) Cyclic lava effusion during the 2018 eruption of Kîlauea volcano. Science 366(6470):eaay9070. https://doi.org/10.1126/ science.aay 9070

Poland MP, Orr TR (2014) Identifying hazards associated with lava deltas. Bull Volcanol 76(12):880. https://doi.org/10.1007/s00445014-0880-0

Rhodes JM (1996) Geochemical stratigraphy of lava flows sampled by the Hawaii Scientific Drilling Project. Journal of Geophysical Research: Solid Earth 101(B5):11729-11746. https://doi.org/10. 1029/95jb03704

Rhodes, J. M., Vollinger, M. J. (2004). Composition of basaltic lavas sampled by phase-2 of the Hawaii Scientific Drilling Project: geochemical stratigraphy and magma types. Geochemistry, Geophysics, Geosystems, 5(3). https://doi.org/10.1029/ $2002 \mathrm{gc} 000434$

Sansone FJ, Smith JR (2006) Rapid mass wasting following nearshore submarine volcanism on Kilauea volcano, Hawaii. J Volcanol Geotherm Res 151(1):133-139. https://doi.org/10.1016/j. jvolgeores.2005.07.026

Sansone FJ, Resing JA, Tribble GW, Sedwick PN, Kelly KM, Hon K (1991) Lava-seawater interactions at shallow-water submarine lava flows. Geophys Res Lett 18(9):1731-1734. https://doi.org/10.1029/ $91 \mathrm{~g} 101279$

Schiffman P, Watters RJ, Thompson N, Walton AW (2006) Hyaloclastites and the slope stability of Hawaiian volcanoes: insights from the Hawaiian Scientific Drilling Project's 3-km drill core. J Volcanol Geotherm Res 151(1):217-228. https://doi.org/ 10.1016/j.jvolgeores.2005.07.030

Skilling IP (2002) Basaltic pahoehoe lava-fed deltas: large-scale characteristics, clast generation, emplacement processes and environmental discrimination. Geol Soc Lond, Spec Publ 202(1):91-113. https://doi.org/10.1144/gsl.sp.2002.202.01.06
Smellie JL, Wilch TI, Rocchi S (2013) 'A'ā lava-fed deltas: A new reference tool in paleoenvironmental studies. Geology 41(4):403-406. https://doi.org/10.1130/g33631.1

Smith, J. R. (2016). Multibeam backscatter and bathymetry synthesis for the main Hawaiian islands final technical report July 2016 By: Dr. John R. Smith, University of Hawai' $i$ Undersea Research Laboratory, pp. 1-15

Soule, S. A. (2015). Mid-ocean ridge volcanism. In H. Sigurdsson, B. Houghton, S. R. McNutt, H. Rymer, J. Stix (Eds.), The Encyclopedia of Volcanoes (pp. 395-403). https://doi.org/10.1016/ b978-0-12-385938-9.00021-3

Soule SA, Heffron E, Gee L, Mayer L, Raineault NA, German CR, Lim DSS, Zoeller M, Parcheta C (2019) Mapping the lava deltas of the 2018 eruption of Kilauea volcano. Oceanography 32(1):46-47

Stearns HT, Macdonald GA (1946) Geology and ground-water resources of the island of Maui, Hawaii. Hawaiian Division of Hydrography Bulletin 9:334. https://doi.org/10.2307/211489

Tribble GW (1991) Underwater observations of active lava flows from Kilauea volcano, Hawaii. Geology 19(6):633-636. https://doi.org/ 10.1130/0091-7613(1991)019<0633:uooalf >2.3.co;2

Watton TJ, Jerram DA, Thordarson T, Davies RJ (2013) Threedimensional lithofacies variations in hyaloclastite deposits. $\mathrm{J}$ Volcanol Geotherm Res 250(C):19-33. https://doi.org/10.1016/j. jvolgeores.2012.10.011

Watts AB, Peirce C, Grevemeyer I, Paulatto M, Stratford W, Bassett D, Hunter JA, Kalnins LM, de Ronde CEJ (2012) Rapid rates of growth and collapse of Monowai submarine volcano in the Kermadec Arc. Nat Geosci 5(7):510-515. https://doi.org/10.1038/ngeo1473

Wilson ST, Hawco NJ, Armbrust EV, Barone B, Björkman KM, Boysen AK, Burgos M, Burrell TJ, Casey JR, DeLong EF, Dugenne M, Dutkiewicz S, Dyhrman ST, Ferrón S, Follows MJ, Foreman RK, Funkey CP, Harke MJ, Henke BA, Hill CN, Hynes AM, Ingalls AE, Jahn O, Kelly RL, Knapp AN, Letelier RM, Ribalet F, Shimabukuro EM, Tabata RKS, Turk-Kubo KA, White AE, Zehr JP, John S, Karl DM (2019) Kîlauea lava fuels phytoplankton bloom in the North Pacific Ocean. Science 365(6457):1040-1044. https://doi.org/10. 1126/science.aax4767

Wright IC, Chadwick WW, de Ronde CEJ, Reymond D, Hyvernaud O, Gennerich H-H, Stoffers P, Mackay K, Dunkin MA, Bannister SC (2008) Collapse and reconstruction of Monowai submarine volcano, Kermadec Arc, 1998-2004. Journal of Geophysical Research: Solid Earth 113(B8). https://doi.org/10.1029/2007jb005138

Yamagishi, H. (1987). Studies on the Neogene subaqueous lavas and hyaloclastites in southwest Hokkaido, Geological Survey of Hokkaido No 59, pp. 55-117

Zimanowski B, Büttner R, Lorenz V (1997) Premixing of magma and water in MFCI experiments. Bull Volcanol 58(6):491-495. https:// doi.org/10.1007/s004450050157 